What have we learned from a decade of empirical research on growth?

\title{
It's Not Factor Accumulation: Stylized Facts and Growth Models
}

\author{
William Easterly and Ross Levine
}

\begin{abstract}
The article documents five stylized facts of economic growth. (1) The "residual" (total factor productivity, TFP) rather than factor accumulation accounts for most of the income and growth differences across countries. (2) Income diverges over the long run. (3) Factor accumulation is persistent while growth is not, and the growth path of countries exhibits remarkable variation. (4) Economic activity is highly concentrated, with all factors of production flowing to the richest areas. (5) National policies are closely associated with long-run economic growth rates. These facts do not support models with diminishing returns, constant returns to scale, some fixed factor of production, or an emphasis on factor accumulation. However, empirical work does not yet decisively distinguish among the different theoretical conceptions of TFP growth. Economists should devote more effort toward modeling and quantifying TFP.
\end{abstract}

The central problem in understanding economic development and growth is not understanding the process by which an economy raises its savings rate and increases the rate of physical capital accumulation. ${ }^{1}$ Although many development practitioners and researchers continue to target capital accumulation as the driv-

William Easterly is senior advisor, Development Research Group, at the World Bank. His e-mail address isweasterly@worldbank.org. Ross Levine is with the University of Minnesota. His e-mail address is rlevine@csom.umn.edu. The authors are grateful to Lant Pritchett, who shaped the paper, gave comments, and provided many of the "stylized facts." They also thank François Bourguignon, Ashok Dhareshwar, Robert G. King, Michael Kremer, Peter Klenow, Paul Romer, Xavier Sala-i-Martin, Robert Solow, Albert Zeufack, two anonymous referees, and students and faculty at the Economics Education Research Consortium program in Kiev, Ukraine, Harvard University's Kennedy School of Government, and Johns Hopkins School of Advanced International Studies for useful comments. An earlier version of this article was presented at the World Bank conference "What Have We Learned from a Decade of Empirical Research on Growth?” held on 26 February 2001.

1. This is a reversal and slight rewording of Arthur Lewis's (1954, p. 155) famous quote, "The central problem in the theory of economic development is to understand the process by which a community which was previously saving and investing 4 or 5 percent of its national income or less, converts itself into an economy where voluntary saving is running at about 12 to 15 percent of national income or more. This is the central problem because the central fact of development is rapid capital accumulation (including knowledge and skills with capital)." Though Lewis recognizes the importance of knowledge and skills and later in his book highlights the importance of institutions, many development economists who followed Lewis adopted the more limited focus on savings and physical capital accumulation.

(C) 2001 The International Bank for Reconstruction and Development / THE WORLD BANK 
ing force in economic growth, 2 "something else" besides capital accumulation is critical for understanding differences in economic growth and income across countries. This conclusion is based on evidence on the sources of economic growth, the patterns of economic growth, the patterns of factor flows, and the impact of national policies on economic growth.

This study does not argue that factor accumulation is unimportant in general or deny that it is critically important for some countries at specific junctures. As Robert Solow noted in 1956, economists construct models to reproduce crucial empirical regularities and then use these models to interpret economic events and make policy recommendations. This article documents important empirical regularities about economic growth with the hope of highlighting productive directions for future research and improving public policy.

\section{Something Else}

A growing body of research suggests that, even after physical and human capital accumulation are accounted for, something else accounts for the bulk of crosscountry differences in the level and growth rate of gross domestic product (GDP) per capita. Economists typically refer to the something else as total factor productivity (TFP). This article follows that convention.

Different theories offer very different conceptions of TFP. These range from changes in technology (the instructions for producing goods and services) to the role of externalities, changes in the sector composition of production, and the adoption of lower-cost production methods. Evidence that confidently assesses how well these conceptions of TFP explain economic growth is lacking. Economists need to provide much more shape and substance to the amorphous term TFP, distinguishing empirically among these different theories.

This article examines five stylized facts that illuminate TFP and its determinants to enable more precise modeling of long-run economic growth and the design of appropriate policies.

2. Academic researchers in the 1990s started a "neoclassical revival" (in the words of Klenow and Rodriguez-Clare 1997b). The classic works in the academic literature's stress on factor accumulation were Mankiw, Romer, and Weil (1992); Barro and others (1995); Mankiw (1995); and Young (1995). The summary of the Global Development Network conference in Prague in June 2000, representing many international organizations and development research institutes, says "physical capital accumulation was found to be the dominant source of growth both within and across regions. Total factor productivity growth (TFPG) was not as important as was previously believed" (www.gdnet.org/pdfs/ GRPPragueMtgReport.pdf). A leading development textbook (Todaro 2000) says that an increase in investment is "a necessary condition" for economic takeoff. The development textbook of Ray (1998, p. 54) refers to investment and saving as "the foundations of all models of economic growth." Many development practitioners also stress investment. For example, the International Monetary Fund (Hadjimichael and others 1996, p. 1) argues, "The adjustment experience of sub-Saharan Africa has demonstrated that to achieve gains in real per capita GDP an expansion in private saving and investment is key." The Bank for International Settlements (1996, p. 50) concludes, "Recent experience has underlined the central importance of national saving and investment rates in promoting growth." And the International Labor Organization $(1995$, p. 12) argues that "policies to raise the rate of investment ... 
- Stylized fact 1. Factor accumulation does not account for the bulk of crosscountry differences in the level or growth rate of GDP per capital; something else-TFP-does. In the search for the secrets of long-run economic growth, a high priority should go to rigorously defining TFP, empirically dissecting it, and identifying the policies and institutions most conducive to its growth.

- Stylized fact 2. There are huge and growing differences in GDP per capita; divergence-not conditional convergence-is the big story. An emphasis on TFP growth with increasing returns to technology is more consistent with divergence than are models of factor accumulation with decreasing returns, no scale economies, and some fixed factor of production. Over the past two centuries, the big story has been the widening difference between the richest and the poorest countries. Moreover, the growth rates of the rich are not slowing, and returns to capital are not falling. Just as business cycles look like little wiggles around the big story when viewed over a long horizon, understanding slow, intermittent conditional convergence seems less intriguing than uncovering why the United States has enjoyed steady growth for 200 years while much of world still lives in poverty.

- Stylized fact 3. Growth is not persistent over time, but capital accumulation is. Some countries take off, others experience peaks and valleys, a few grow steadily, and some have never grown. Changes in factor accumulation do not closely track changes in economic growth. This finding is consistent across very different frequencies of data. Tangentially, but critically, this stylized fact also suggests that models of steady-state growth, whether based on capital externalities or technological spillovers, will not capture the experiences of many countries. While steady-state growth models may fit U.S. experience over the past 200 years, these models will not fit the experiences of Argentina, the Republic of Korea, Thailand, or Venezuela very well. In contrast, models of multiple equilibria do not fit the U.S. data very well. Thus models tend to be country-specific rather than general theories. Meanwhile, empirical work is still going on to explain why the United States is different, how

are critical for raising the rate of growth and employment in an economy." Finally "additional investment is the answer-or part of the answer-to most policy problems in the economic and social arena" (United Nations 1996, p. 8). Similarly, the World Bank (1993, p. 191) states that in East Asia, "accumulation of productive assets is the foundation of economic growth." World Bank (1995, p. 10, 23) promises that in Latin America "enhancing saving and investment by 8 percentage points of GDP would raise the annual growth figure by around 2 percentage points." The World Bank (2000a, p. 10) says the saving rate of the typical African country "is far below what is needed to sustain a long-term boost in economic performance." The World Bank (2000c, p. 1) says that southeastern Europe can seize trade opportunities only if "domestic and foreign entrepreneurs increase their investment dramatically." For more citations, see Easterly (1999a) and King and Levine (1994). Although common, the stress on capital accumulation is far from universal among development practitioners and researchers. For example, the World Bank (2000b, p. 4) report on East Asia's recovery suggests that "future growth hinges less on increasing physical capital accumulation and more on raising the productivity growth of all factors." Collier, Dollar, and Stern (2000) stress policies, incentives, institutions, and exogenous factors as the main drivers in growth with little mention of investment, as does World Development Report 2000/ 2001 (World Bank 2000/2001, pp. 49-52). 
Argentina can go from being like the United States early in this century to the struggling middle-income country it is today, and how Korea or Thailand can go from being like Somalia to having thriving economies.

- Stylized fact 4. All factors of production flow to the same places, suggesting important externalities. Although this has been noted and modeled by Lucas (1988), Kremer (1993), and others, this article further demonstrates the pervasive tendency for all factors of production, including physical and human capital, to bunch together. As a consequence, economic activity is highly concentrated. This tendency holds whether considering the world, countries, regions, states, ethnic groups, or cities. Thus the something else that accounts for the bulk of differences in growth across these units needs to be fleshed out and given a prominent position in theories and policy recommendations.

- Stylized fact 5. National policies influence long-run growth. In models with zero productivity growth, diminishing returns to factors of production, and some fixed factor, national policies that boost physical or human capital accumulation have only a transitional effect on growth. In models that emphasize TFP growth, national policies that enhance the efficiency of capital and labor or alter the endogenous rate of technological change can boost productivity growth and accelerate long-run economic growth. Thus the finding that policy influences growth is consistent with theories that emphasize productivity growth and technological externalities and cast increasing doubt on theories that focus excessively on factor accumulation.

Although many economists have examined TFP growth and assessed growth models, this article makes several new contributions. Besides conducting traditional growth accounting with new Penn-World Table 5.6 capital stock data, this article fully exploits the panel nature of the data. Using an international crosssection of countries, it addresses two questions:

- What accounts for cross-country growth differences?

- What accounts for growth differences over time?

Overwhelmingly the answer is TFP, not factor accumulation.

The article also examines differences in the level of GDP per worker across countries. It updates Denison's (1962) original level accounting study and extends Mankiw, Romer, and Weil's (1992) study by allowing technology to differ across countries and by assessing the importance of country-specific effects. Unlike Mankiw, Romer, and Weil (1992), it finds that large differences in TFP account for the bulk of cross-country differences in income per capita, even controlling for country-specific effects.

The article also compiles new information documenting massive divergence in the level of income per capita across countries. Although many studies base their modeling strategies on the U.S. experience of steady long-run growth (see, for example, Jones 1995a, 1995b; and Rebelo and Stokey 1995), the U.S. experience is the exception. In much of the world miracles and disasters and changing long-run 
growth rates are the rule, not stable long-run growth rates. Finally, the article presents abundant new evidence on the concentration of economic activity, drawing on cross-country information, county-level data for the United States, developing country studies, and information on the international flow of capital, labor, and human capital to demonstrate the geographic concentration of activity and relate this to models of economic growth. The overwhelming concentration of economic activity is consistent with some theories of economic growth and inconsistent with others. Though individual countries at specific points in their development fit different models of growth, the big picture emerging from cross-country growth comparisons is that creating the incentives for productive factor accumulation is more important for growth than factor accumulation itself.

\section{Stylized Fact i. It’s Not Factor Accumulation, It's tfp}

Although physical and human capital accumulation may play key roles in igniting and accounting for economic progress in some countries, something else-TFPaccounts for the bulk of cross-country differences in the level and growth of GDP per capita in a broad cross-section of countries. The empirical importance of TFP has motivated economists to develop models of TFP. These focus variously on technological change (Aghion and Howitt 1998; Grossman and Helpman 1991; Romer 1990); impediments to adopting new technologies (Parente and Prescott 1996); externalities (Romer 1986; Lucas 1988); sectoral development (Kongsamut, Rebelo, and Xie 1997); or cost reductions (Harberger 1998).

This section briefly presents evidence on factor accumulation and growth and discusses the implications for models and policy. It considers three questions. First, what part of a country's growth rate is accounted for by factor accumulation and TFP growth? Looking at the sources of growth in individual countries over time helps answer this question. Second, what part of cross-country differences in economic growth rates is accounted for by cross-country differences in growth rates of factor accumulation and TFP? Third, what part of the intertemporal difference in economic growth rates is accounted for by time-series differences in growth rates of factor accumulation and TFP? Traditional growth accounting forms the basis for answering these questions.

\section{Growth Accounting}

The organizing principle of growth accounting is the Cobb-Douglas aggregate production function:

$$
y=A k^{\alpha}\left(n^{1-\alpha}\right),
$$

where $y$ is national output per person, ${ }^{3} A$ is technological progress, $k$ is the physical capital stock per person, $n$ is the number of units of labor input per person

3. We switch between output per worker and output per person depending on data availability and what's appropriate for each usage. 
(reflecting work patterns, human capital, and the like), and $\alpha$ is a production function parameter (equal to the share of capital income in national output under perfect competition).

Output growth is then divided into components attributable to changes in the factors of production. Rewriting equation 1 in growth rates:

$$
(\Delta y / y)=(\Delta A / A)+\alpha(\Delta \mathrm{k} / \mathrm{k})+(1-\alpha)(\Delta n / n) \text {. }
$$

Consider a hypothetical country with a growth rate of output per person of 2 percent, growth in capital per capita of 3 percent, growth in human capital of 0 , and capital's share of national income of 40 percent $(\alpha=0.4)$. In this example, TFP growth is 0.8 percent, and therefore, TFP-growth accounts for 40 percent $(0.8 / 2)$ of output growth in this country.

Detailed GRowth accounting. Many researchers conduct detailed growth accounting exercises of one or a few countries, using disaggregated data on capital, labor, human capital, and capital shares of income. Early, detailed growth accounting exercises of a few countries by Solow (1957) and Denison (1962, 1967) found that the rate of capital accumulation per person accounted for between one-eighth and one-fourth of GDP growth rates in the United States and other industrialized countries, whereas TFP-growth accounted for more than half of GDP growth in many countries.

Subsequent studies showed that it is important to account for changes in the quality of labor and capital (see papers in Jorgenson 1995). For example, if growth accountants fail to consider improvements in the quality of labor inputs due to improved education and health, they would assign these improvements to TFP growth. Unmeasured improvements in physical capital would similarly be inappropriately assigned to TFP. Nonetheless, to the extent that TFP includes quality improvements in capital, a finding that TFP explains a substantial amount of economic growth will properly focus attention on productivity rather than on factor accumulation itself.

Later detailed growth accounting exercises for a few countries incorporated estimates of such changes in the quality of human and physical capital (table 1). ${ }^{4}$ These studies also find that TFP growth tends to account for a large component of the growth of output. Christenson, Cummings, and Jorgenson (1980) do this for a few Organisation for Economic Co-operation and Development (OECD) countries, albeit prior to the productivity growth slowdown. Dougherty (1991) does the exercise for some OECD countries including the slow productivity growth period. Elias (1990) conducts a rigorous growth accounting study for seven Latin American countries. Young (1995) focuses on fast growing East Asian countries. Although there are large cross-country variations in the fraction of growth accounted for by TFP growth, some general patterns emerge. TFP growth accounts

4. We use the summary in Barro and Sala-i-Martin (1995, pp. 380-81). 
for about half of output growth in OECD countries. Variation is greater among Latin American countries, with an average of 30 percent. Young (1995) argues that factor accumulation was a key component of the growth miracle in some East Asian economies.

These detailed growth accounting exercises may seriously underestimate the influence of TFP growth on growth in output per worker as emphasized by Klenow and Rodriguez-Clare (1997a). The studies summarized in table 1 examine output growth. If the analysis is adjusted to focus on output per worker, TFP growth accounts for a much larger share of output per worker growth than for the output growth figures in table 1. In an extension of Young (1995), Klenow and Rodriguez-Clare (1997a) show that factor accumulation plays the crucial role

TABle 1. Selected Growth Accounting Results for Individual Countries (percent)

\begin{tabular}{|c|c|c|c|c|c|}
\hline \multirow[b]{2}{*}{ Economy } & \multirow{2}{*}{$\begin{array}{c}\text { Share of capital } \\
\text { in national } \\
\text { output }\end{array}$} & \multirow[b]{2}{*}{ GDP growth } & \multicolumn{3}{|c|}{ Share contributed by } \\
\hline & & & Capital & Labor & TFP \\
\hline \multicolumn{6}{|l|}{ OECD 1947-73 } \\
\hline France & .40 & 5.40 & 41 & 4 & 55 \\
\hline Germany & .39 & 6.61 & 41 & 3 & 56 \\
\hline Italy & .39 & 5.30 & 34 & 2 & 64 \\
\hline Japan & .39 & 9.50 & 35 & 23 & 42 \\
\hline United Kingdom & .38 & 3.70 & 47 & 1 & 52 \\
\hline United States & .40 & 4.00 & 43 & 24 & 33 \\
\hline \multicolumn{6}{|l|}{ OECD 1960-90 } \\
\hline France & .42 & 3.50 & 58 & 1 & 41 \\
\hline Germany & .40 & 3.20 & 59 & -8 & 49 \\
\hline Italy & .38 & 4.10 & 49 & 3 & 48 \\
\hline Japan & .42 & 6.81 & 57 & 14 & 29 \\
\hline United Kingdom & .39 & 2.49 & 52 & -4 & 52 \\
\hline United States & .41 & 3.10 & 45 & 42 & 13 \\
\hline \multicolumn{6}{|l|}{ Latin America 1940-80 } \\
\hline Argentina & .54 & 3.60 & 43 & 26 & 31 \\
\hline Brazil & .45 & 6.40 & 51 & 20 & 29 \\
\hline Chile & .52 & 3.80 & 34 & 26 & 40 \\
\hline Mexico & .69 & 6.30 & 40 & 23 & 37 \\
\hline Venezuela & .55 & 5.20 & 57 & 34 & 9 \\
\hline \multicolumn{6}{|l|}{ East Asia 1966-90 } \\
\hline Hong Kong, China & .37 & 7.30 & 42 & 28 & 30 \\
\hline Singapore & .53 & 8.50 & 73 & 32 & -5 \\
\hline Korea, Rep. of & .32 & 10.32 & 46 & 42 & 12 \\
\hline Taiwan, China & 0.29 & 9.10 & 40 & 40 & 20 \\
\hline
\end{tabular}

Source: For OECD, Christenson, Cummings, and Jorgenson (1980) and Dougherty (1991); for Latin America, Elias (1990); for East Asia, Young (1995). 
only in Singapore (a small city-state) but in none of the other East Asian miracle economies. In addition, the share attributed to capital accumulation may be exaggerated because it does not take into account how much TFP growth induces capital accumulation (Barro and Sala-i-Martin 1995, p. 352.)

In sum, although there are cases in which factor accumulation is closely tied to economic success, detailed growth accounting examinations suggest that TFP growth frequently accounts for the bulk of growth in output per worker.

Aggregate growth Accounting. There are also aggregate growth accounting exercises of a large cross-section of countries that use a conglomerate measure of capital and an average value of the capital share parameter from microeconomic studies. King and Levine (1994) and Nehru and Dhareshwar (1994) make some initial estimates of the capital stocks of countries in 1950. They then use aggregate investment data and assumptions about depreciation rates to compute capital stocks in later years for over 100 countries. The importance of the estimate of the initial capital stock diminishes over time due to depreciation.

This study uses the new Penn-World Table (РWT) 5.6 capital stock data, based on disaggregated investment and depreciation statistics for 64 countries. Though these data exist for a smaller number of countries, they suffer from fewer aggregation and measurement problems than the aggregate growth accounting exercises using less precise data. ${ }^{5}$

5. The Penn World Tables document the construction of these data. Capital stock figures were also constructed for more countries using aggregate investment figures. For some countries, the data start in 1951. These data use real investment in 1985 prices and real GDP per capita (chain index) in constant 1985 prices. A perpetual inventory method was used to compute capital stocks. Specifically, let $K(t)$ equal the real capital stock in period $t$. Let $I(t)$ equal the real investment rate in period $t$. Let $d$ equal the depreciation rate, assumed to be .07 . Thus, the capital accumulation equation states that $K(t+1)=(1$ $-d) K(t)+I(t)$. To compute the capital per worker ratio, divide $K(t)$ by $L(t)$, where $L(t)$ is the working age population in period $t$ as defined in the Penn World Tables. To compute the capital-output ratio, divide $K(t)$ by $Y(t)$, where $Y(t)$ is real GDP per capita in period $t$. To make an initial estimate of the capital stock, we make the assume that the country is at its steady-state capital-output ratio. Thus in terms of steady-state value, let $k=K / Y$, let $g=$ the growth rate of real output, let $i=I / Y$. Then, from the capital accumulation equation plus the assumption that the country is at its steady-state, $k=i /(g+d)$. Thus, with reasonable estimates of the steady-state values of $i, g$, and $d$, a reasonable estimate of $k$ can be computed. The Penn World Tables have data on output back to 1950. Thus, the initial capital stock estimate can be computed as $k Y$ (initial). To make the initial estimate of $k$, the steady state capital output ratio, set $d=.07$. The steady-state growth rate $g$ is computed as a weighted average of the countries average growth rate during the first ten years for which we have output and investment data and the world growth rate, computed as 0.0423. Based on Easterly and others (1993), the world growth rate is given a weight of 0.75 and the country growth rate 0.25 in computing an estimate of the steady-state growth rate for each country. Then $i$ can be computed as the average investment rate during the first ten years for which there are data. Thus, with values for $d, g$, and $i$ for each country, $k$ can be estimated for each country. Average real output value between 1950-52 is used as an estimate of initial output, $Y$ (initial), to reduce the influence of business cycles in estimating $Y$ (initial). Thus the capital stock in 1951 is given as $Y$ (initial) $k$. If output and investment data do not start until 1960, everything is moved up one decade for that country. Given depreciation, the guess at the initial capital stock becomes relatively unimportant decades later. 
The aggregate growth accounting results for a broad selection of countries also emphasize TFP's role in economic growth. There is enormous cross-country variation in the fraction of growth accounted for by capital and TFP growth. In the average country, considering only physical capital accumulation, TFP growth accounts for about 60 percent of growth in output per worker using the PWT 5.6 capital data and setting the share of capital in national output $(\alpha)$ at .4 , which is consistent with individual country studies. Other measures of the capital stock from King and Levine (1994) and Nehru and Dhareshwar (1993) yield similar results.

Aggregate growth accounting results are illustrated in figure 1 using data from PWT 5.6 for 1980-92. Countries are grouped by decile based on output per capita growth, from the slowest growing (group 1) to the fastest. Capital growth generally accounts for less than half of output growth, and the share of growth accounted for by TFP growth is frequently larger in the faster growing countries. There are large differences across countries in the relationship between capital accumulation and growth. For example, Costa Rica, Ecuador, Peru, and Syria all saw real per capita GDP fall by more than 1 percent a year, while real per capita capital stocks grew by more than 1 percent a year and educational attainment was rising. Clearly, these factor injections were not being used productivity. Albeit unrepresentative, these cases illustrate the shortcoming of focusing too heavily on factor accumulation. ${ }^{6}$

Incorporating estimates of human capital accumulation into these aggregate growth accounting exercises does not materially alter the findings. In the average country, TFP growth still accounts for more than half of growth in output per worker. Moreover, the data suggest a weak-and sometimes inverse-relationship between improvements in educational attainment of the labor force and growth of output per worker growth. Benhabib and Spiegel (1994) and Pritchett (2001), using cross-country data on economic growth rates, show that increases in human capital resulting from improvements in educational attainment have not positively affected the growth in output per worker (perhaps because of a mismatch between education and the skills needed for activities that generate social returns).

There is disagreement, however. Krueger and Lindahl (1999) argue that measurement error accounts for the failure to find a relationship between growth per capita and human capital accumulation. Hanushek and Kimko (2000) find that the quality of education is strongly linked with economic growth. Klenow (1998) demonstrates that models that highlight the role of ideas and productivity growth do a much better job of matching the data than models that focus on the accumulation of human capital. More work is needed on the relationship between education and economic development.

6. It may be that the conventional measure of investment effort is a cost-based measure that does not translate necessarily into increasing the value of the capital stock. Pritchett (1999) makes this point, especially—but not only-with regard to public investment. 
FIgure 1. Growth Accounting: Growth Rates by Decile

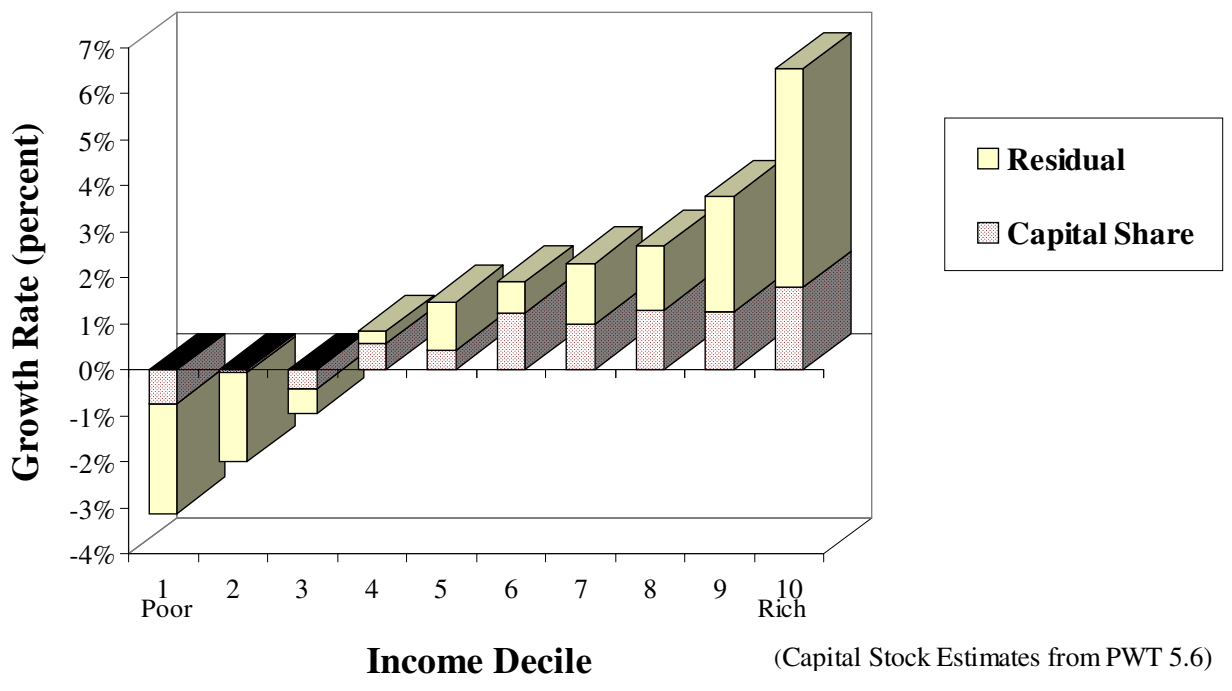

\section{Variance Decomposition}

Although traditional growth accounting measures that part of a country's growth rate that may be attributable to factor accumulation, this study uses variance decomposition to construct indicators of that part of cross-country differences in economic growth rates accounted for by cross-country differences in TFP and factor growth (Jones 1997). Assuming that $\alpha=.4$, the following holds for the cross-section of countries:

$$
\begin{gathered}
\operatorname{VAR}(\Delta y / y)=\operatorname{VAR}(\Delta T F P / T F P)+(0.4)^{2}\{\operatorname{VAR}(\Delta k / k)\}+ \\
2(0.4)\{\operatorname{COV}(\Delta T F P / T F P, \Delta k / k)\} .
\end{gathered}
$$

Decomposing the sources of growth across countries using different data sets shows that cross-country variations in TFP growth account for more that 60 percent of output growth using alternative data sets (table 2). The cross-country variation in physical capital alone-excluding the covariance with TFP growthnever accounts for more than 25 percent of the cross-country variation in per capita GDP growth.

Researchers also incorporate human capital accumulation into decomposition exercises, rewriting the variance-decomposition equations as:

$$
\begin{gathered}
\operatorname{VAR}(\Delta y / y)=\operatorname{VAR}(\Delta \operatorname{TFP} / T F P)+(0.7)^{2}\{\operatorname{VAR}(\Delta f / f)\}+ \\
2(0.7)\{\operatorname{COV}(\Delta \operatorname{TFP} / T F P, \Delta f / f)\},
\end{gathered}
$$

where $\Delta f / f$ is factor accumulation per worker, defined as the average growth rate of physical capital per worker and educational attainment per worker. Specifically, $\Delta f / f=(\Delta k / k+\Delta h / h) / 2$, where $h$ is educational attainment per worker. ${ }^{7}$

7. Again, different authors use different weights, though this tends not to change the basic findings. 
TABle 2. Variance Decomposition

\begin{tabular}{lccc}
\hline & \multicolumn{3}{c}{ Contribution of } \\
\cline { 2 - 4 } & TFP growth & Capital growth & $\begin{array}{c}\text { Covariance of } \\
\text { capital growth } \\
\text { TFP growth }\end{array}$ \\
\hline $\begin{array}{l}\text { Without human capital } \\
\text { 1960-92 }\end{array}$ & 0.58 & 0.41 & 0.01 \\
1980-92 & 0.65 & 0.21 & 0.13 \\
$\begin{array}{l}\text { With human capital } \\
\text { 1960-92 }\end{array}$ & 0.94 & 0.52 & -0.45 \\
1980-87c & 0.68 & 0.20 & 0.12 \\
\hline
\end{tabular}

aSixty non-oil-exporting countries.

bForty-four countries.

cFifty countries.

Source: Authors's calculations based on the PwT 5.6 capital stock series and Benhabib and Spiegel's (1994) estimates of human capital growth.

Incorporating human capital does not alter the basic result. TFP growth differentials account for the bulk of cross-country growth differences. Klenow and Rodriguez-Clare (1997b) estimate that differences in TFP growth account for about 90 percent of the variation in growth rates of output per worker for a sample of 98 countries during 1960-95 after accounting for human capital accumulation (based on schooling and job experience). The use of the PWT 5.6 capital stock series and estimates of the growth rate of human capital from Benhabib and Spiegel (1994) also shows that differences in TFP growth account for about 90 percent of cross-country differences in real per capita GDP growth during 1960-92. Thus differences in TFP growth-rather than in factor accumulation rates-seem like the natural place to start in explaining cross-country differences in long-run growth rates.

Growth accounting has several limitations. It is a mechanical procedure, and using it to elucidate a causal story is dangerous. For example, in Solow's (1956) model, if technological progress $(A)$ grows at the exogenously given steadystate rate $x$, then $y$ and $k$ grow at the steady-state rate $x$, too. Growth accounting will, therefore, attribute $\alpha x$ of output growth to capital growth, yielding the conclusion that $\alpha$ times 100 percent of growth is due to physical capital accumulation. Also, growth accounting does not test the statistical significance of the relationship between output growth and capital accumulation. (The temporal-Granger-causal—relationships between growth and savings, investment, and education are discussed later.)

Level accounting AND THE K/Y RATiO. Hall and Jones (1999) recently reexamined the level accounting question, asking what part of cross-country differences in income per capita is accounted for by differences in physical capital per capita. They find that productivity differences across countries account for the bulk of cross-country differences in output per worker. This study addresses this 
question using the traditional Denison (1962) approach and a modified Mankiw, Romer, and Weil (1992) approach.

To conduct Denison-level accounting, take the ratio of two national incomes of output per person from equation 1:

$$
\left[y_{i} / y_{i}\right]=\left[A_{i} / A_{j}\right]\left[k_{i} / k_{j}\right]^{\alpha}\left[n_{i} / n_{j}\right]^{1-\alpha} .
$$

Given data on the factors of production, cross-country differences in TFP can be measured by:

$$
\left[A_{i} / A_{j}\right]=\left[y_{i} / y_{j}\right] /\left\{\left[k_{i} / k_{j}\right]^{\alpha}\left[n_{i} / n_{j}\right]^{1-\alpha}\right\}
$$

The fraction of differences in national output levels due to capital equals the ratio, $\phi_{k i}$.

$$
\phi_{k i}=\alpha \log \left(k_{i} / k_{j}\right) / \log \left(y_{i} / y_{j}\right) .
$$

Equation 7 can be rewritten as:

$$
\phi_{k i}=\alpha+\alpha \log \left(k_{i} / k_{j}\right) / \log \left(y_{i} / y_{j}\right),
$$

because $\log \left(k_{i} / k_{j}\right)=\log \left(\kappa_{\mathrm{i}} / \kappa_{\mathrm{j}}\right)-\log \left(y_{y i} / y_{j}\right)$, letting $\kappa=k / y$. This allows measurement of the contribution of capital due to capital share $(\alpha)$ and that due to differences in the capital-output ratios. If capital-output ratios are constant across countries $i$ and $j$, then the contribution of capital due to differences in output per capita in countries $i$ and $j$ simply equals $\alpha$.

To conduct level accounting, first calculate the percentage shortfall in output of country $i$ relative to the reference country $j . P_{i}=100\left(y_{j}-y_{i}\right) / y_{j}$. Then construct the contribution of capital due to the output difference as, $P_{i} \phi_{k i}$. As in King and Levine (1994), the level accounting uses figures on aggregate capital stocks (but from PWT 5.6). Countries are classified into five groups, from poorest to richest. The richest group is the reference group.

Figure 2 summarizes the level accounting results. Group 1, the poorest, has more than a 90 percent shortfall in GDP per capita relative to the reference group. TFP accounts for the bulk of cross-country differences in levels of income per capita. The rest is due to capital share of output, assuming constant capital-output ratios, and to the tendency for capital-output ratios to rise with income per capita. Even accounting for systematic cross-country differences in capital-output ratios, the data indicate that capital differences account for less than 40 percent of the cross-group differences in income per capita. ${ }^{8}$

8. Though not directly related to growth accounting, note that the $K / Y$ ratio systematically varies with income per capita. Capital-output ratios are systematically larger in richer countries; and, capitaloutput ratios tend to rise as countries grow, which are inconsistent with Kaldor's stylized fact on capitaloutput ratios. Consider the regression of the capital-output ratio (кi) on a measure of income per capita relative to that in the United States in the 1980s (yi/yUSA). The regression yields the following result:

$\kappa \mathrm{i}=0.76+0.59[y \mathrm{i} / y \mathrm{USA}]$,

(0.10) (0.18) 
Figure 2. Development Accounting by Income Quintiles (57 Non-Oil-Exporting Countries)

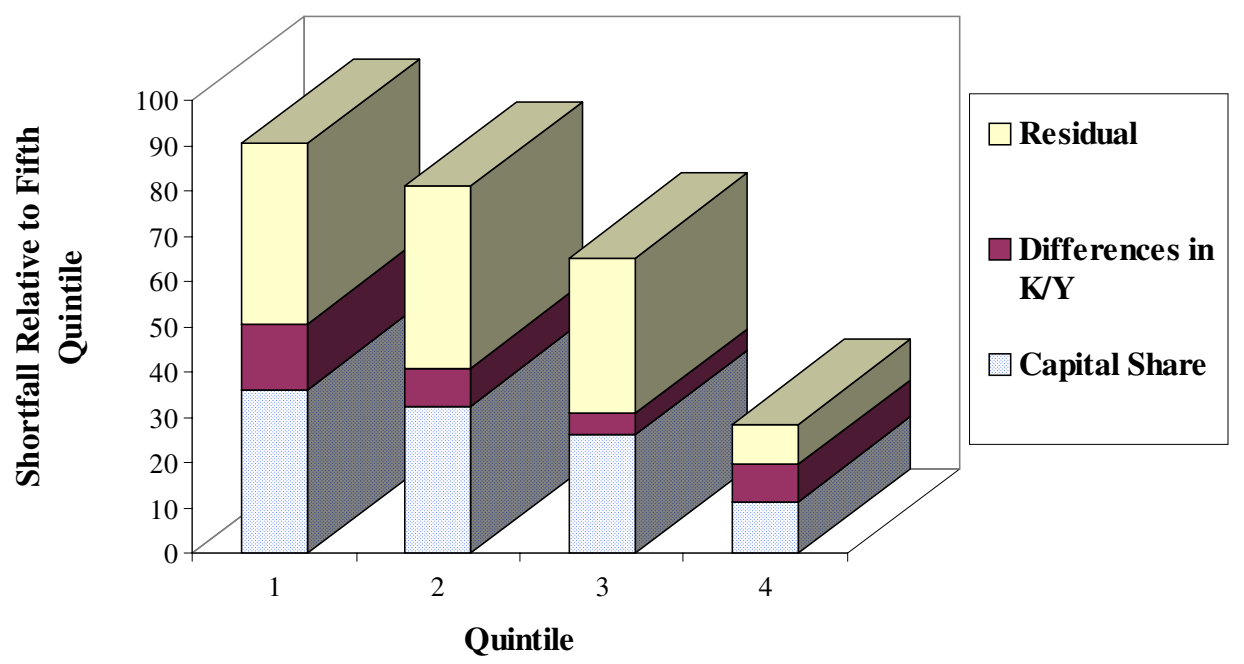

Note: Data cover 57 non-oil-exporting countries.

Source: Authors' calculations based on Penn World Table 5.6 for capital stock estimates.

Mankiw, Romer, AND Weil (MRW) LEVel AcCounting. A second approach to level accounting is suggested by Mankiw, Romer, and Weil (1992), who argue that the Solow model does a good job of accounting for cross-country differences in the level of income per capita. In the steady-state of the Solow model, output per person is given by:

$$
Y / L=A[s /(x+\delta+n)]^{\alpha /(1-\alpha)},
$$

where $Y / L$ is output per person, $A$ is the level of labor-augmenting productivity, $s$ is the ratio of investment to GDP, $x$ is the rate of labor-augmenting productivity growth, $\delta$ is depreciation, $n$ is population growth, and $\alpha$ is the share of capital income in GDP. A 2 percent productivity growth rate and a 7 percent depreciation rate are assumed. Logs are taken of both sides, and the log of output per person is regressed on a constant $(\ln A)$ and on the $\log$ of the second multiplicative term in equation 9:

where $\kappa i$ is the capital-output ratio in country $i$, standard errors are in parentheses, and the regression includes 57 non-oil-exporting countries. There is a strong positive relationship between output per person relative to the United States and the $K / Y$ ratio. Also, figure 3 shows that the $K / Y$ ratio tends to rise in fast growing countries. Here, the average value of $K / Y$ ratios are plotted year by year for countries with per capita growth rates higher than 3.5 percent a year over the period 1960-92. The K/Y ratio rises rapidly over this fast growth period. Though these differences might be due to transitional dynamics, past works suggests that physical capital accumulation along the transition path is unlikely to explain fully level and growth differences (King and Rebelo 1993). 


$$
\ln (Y / L)=\ln A+\alpha /(1-\alpha)[\ln s-\ln (x+\delta+n)] .
$$

This second term will be called MRW.

The MRW approach is then extended by allowing $A$ to differ across regions, oil-producing and non-oil-producing countries, and OECD and non-OECD countries. (The regions are all-inclusive; the OECD and OIL dummy variables measure shifts relative to their respective regions.)

Though there is a significant correlation of income with the MRW investment term (consistent with the Solow model), the results in table 3 refute the original MRW idea that productivity levels are the same across countries. South Asia and Sub-Saharan Africa have significantly lower productivity than other regions (income differences that are not explained by the MRW term). The OECD has higher productivity than the rest of the world by a factor of $3\left(e^{1.087}\right)$. Once the productivity level is allowed to vary, the coefficient on MRW implies a capital share of .31-which is in line with most estimates from national income accounting.

Mankiw, Romer, and Weil report that they are even more successful at explaining cross-country income differences when they include a measure of human capital investment, which they define as $\left[\ln s_{b}-\ln (x+\delta+n)\right]$. They define the flow of investment in human capital $s_{b}$ as the secondary enrollment ratio times the proportion of the labor force of secondary school age. Klenow and RodriguezClare (1997b) and Romer (1995) criticize this measure as overestimating the cross-country variation in human capital by ignoring primary enrollment, which varies much less across countries than secondary enrollment. The results for this

TABle 3. MRw Least Squares Regression with Regional, Oil, and oecd Dummy Variables

\begin{tabular}{lrccr}
\hline Variable & Coefficient & Standard error & $t$-statistic & Probability \\
\hline OECD & 1.087817 & 0.107084 & 10.15857 & 0.0000 \\
East Asia & 7.559995 & 0.176696 & 42.78525 & 0.0000 \\
South Asia & 7.065895 & 0.139239 & 50.74634 & 0.0000 \\
Sub-Saharan Africa & 6.946945 & 0.090968 & 76.36658 & 0.0000 \\
Western Hemisphere & 7.838313 & 0.102363 & 76.57349 & 0.0000 \\
Middle East and North Africa & 7.777138 & 0.143632 & 54.14642 & 0.0000 \\
Europe & 7.717543 & 0.133190 & 57.94384 & 0.0000 \\
OIL & 0.691058 & 0.157605 & 4.384760 & 0.0000 \\
MRW & 0.442301 & 0.096847 & 4.567031 & 0.0000 \\
$R^{2}$ & 0.752210 & Mean dependent variable & 7.79 \\
Adjusted $R^{2}$ & 0.738969 & Standard error of dependent & 0.994 \\
Standard error of regression & 0.508076 & variable & \\
Sum of squared residual & 33.81651 & Schwarz criterion & 1.539 \\
Log likelihood & -98.99247 & F-statistic & 56.810 \\
& \multicolumn{4}{c}{ Probability (F-statistic) } \\
\hline
\end{tabular}

Note: Average log income per capita in 1960-95 is the dependent variable. Number of observations $=139$. Standard errors and covariance are White heteroskedasticity-consistent.

Source: Authors' calculations based on World Bank data. 
new regression show that although the human capital investment term is highly significant, the original physical capital investment term is only marginally significant (table 4). The OECD productivity advantage and the regional differences in productivity are of the same magnitude as before.

When equation 10 is estimated in first differences from the first half of the period to the second to eliminate country fixed effects, the MRW variable is not statistically significant while TFP growth-the constant in the equation in first differences - varies significantly across regions. This is consistent with the earlier finding that most of the cross-country variation in growth rates per capita is do to differences in TFP growth and not to transitional dynamics between steady states.

\section{Causality}

Growth accounting is different from causality. Factor accumulation could ignite productivity growth and overall economic growth. Thus factor accumulation could cause growth even though it does not account for much the crosscountry differences in growth rates in the level of GDP per capita. If this were the case, it would be both analytically appropriate and policy wise to focus on factor accumulation. There is also the well-known cross-section correlation between investment share and growth (see Levine and Renelt 1992).

Evidence suggests, however, that physical and human capital accumulation do not cause faster growth. For instance, Blomstrom, Lipsey, and Zejan (1996) show that output growth Granger-causes investment. Injections of capital do not seem to be the driving force of future growth. Similarly, Carroll and Weil (1993)

TABle 4. MRW Least Squares Regression Including Human Capital, with Regional, Oil, and OECD Dummy Variables

\begin{tabular}{lcccc}
\hline Variable & Coefficient & Standard error & $t$-statistic & Probability \\
\hline OECD & 0.999172 & 0.126361 & 7.907255 & 0.0000 \\
East Asia & 8.040507 & 0.212161 & 37.89818 & 0.0000 \\
South Asia & 7.593671 & 0.184937 & 41.06093 & 0.0000 \\
Sub-Saharan Africa & 7.636055 & 0.207923 & 36.72545 & 0.0000 \\
Western Hemisphere & 8.285468 & 0.136361 & 60.76117 & 0.0000 \\
Middle East and North Africa & 8.345100 & 0.192838 & 43.27516 & 0.0000 \\
Europe & 8.222288 & 0.161656 & 50.86290 & 0.0000 \\
OIL & 0.618785 & 0.179383 & 3.449517 & 0.0008 \\
MRW & 0.168531 & 0.095305 & 1.768343 & 0.0796 \\
MRWH & 0.433868 & 0.089235 & 4.862086 & 0.0000 \\
$R^{2}$ & 0.812286 & Mean dependent variable & 7.779659 \\
Adjusted $R^{2}$ & 0.797722 & Standard error of dependent variable & 1.024315 \\
Standard error of regression & 0.460689 & Akaike information criterion & 1.363849 \\
Sum of squared residual & 24.61913 & Schwarz criterion & 1.588951 \\
Log likelihood & -75.92250 & F-statistic & 55.77363 \\
& \multicolumn{4}{c}{ Probability (F-statistic) } \\
\hline
\end{tabular}

Note: Average log income per capita in 1960-95 is the dependent variable. Number of observations $=126$. Standard errors and covariance are White heteroskedasticity-consistent.

Source: Authors' calculations based on World Bank data. 
show that causality tends to run from output growth to savings, not the other way around. Evidence on human capital tells a similar story. Bils and Klenow (1996) argue that the direction of causality runs from growth to human capital, not from human capital to growth. Thus in terms of both physical and human capital, the data do not provide strong support for the contention that factor accumulation ignites faster growth in output per worker.

\section{Summary}

Although there are important exceptions, as Young (1995) makes clear, "something else" besides factor inputs accounts for the bulk of cross-country differences in income per capita and growth rates. Furthermore, although growth accounting does not show causality, research suggests that increases in factor accumulation do not ignite faster output growth in the future. While more work is needed, the evidence does not suggest that causality runs from physical or human capital accumulation to economic growth in the broad cross-section of countries. Finally, measurement error may reduce confidence in growth and level accounting. However, the residual is large in both level and growth accounting. Also, level and growth accounting for the 1950s and 1960s produce similar estimates as those for the 1990s. This implies that measurement error would have to have two systematic components. Both the growth rate of measurement error and the level component of measurement error would have to be positive and large in rich, fast-growing countries. Measurement problems may play a role, but a considerable body of evidence suggests that something else-TFP-besides factor accumulation is critical for understanding cross-country differences in the level and growth of GDP per capita.

In giving theoretical content to this residual, Grossman and Helpman (1991), Romer (1990) and Aghion and Howitt (1998) focus on technology, on better instructions for combining raw materials into useful products and services. Romer (1986), Lucas (1988), and others focus on externalities, including spillovers, economies of scale, and various complementarities in explaining the large role played by TFP. ${ }^{9}$ Harberger (1998) views TFP as real cost reductions and urges economists not to focus on one underlying cause of TFP because several factors may produce real costs reductions in different sectors of the economy at different times. ${ }^{10}$ This is consistent with industry studies that reveal considerable crosssector variation in TFP growth (Kendrick and Grossman 1980). Prescott (1998) also focuses on technology. He suggests that cross-country differences in resistance to the adoption of better technologies—arising from politics and policieshelp explain cross-country differences in TFP (see Holmes and Schmitz 1995; Parente 1994; Parente and Prescott 1996; and Shleifer and Vishny 1993). It would

9. Yet, Burnside (1996) presents evidence suggesting that physical capital externalities are relatively unimportant. Klenow (1998) presents evidence that is consistent with technological change-based model of growth.

10. Costello (1993) shows that TFP has a strong country component and is not specific to particular industries. 
be useful in designing models and policies to determine empirically the relative importance of each of these conceptions of TFP.

\section{Stylized Fact 2. Divergence, Not Convergence, Is THE BIG STORY}

Over the very long run, there has been "divergence, big time," in the words of Pritchett (1997). The richest countries in 1820 subsequently grew faster than the poorest countries in 1820. The ratio of richest to poorest went from 6 to 1 in 1820 to 70 to 1 in 1992 (figure 3). Prior to the Industrial Revolution (1700-50), the difference between the richest and poorest countries was probably only about 2 to 1 (Bairoch 1993, pp. 102-6). Thus, the big story over the past 200-300 years is one of massive divergence in the levels of income per capita between the rich and the poor. ${ }^{11}$

The poor are not getting poorer, but the rich are getting richer a lot faster than the poor. Absolute divergence has continued over the past 30 years, though not as dramatically as in earlier periods (see table 5). And while China and Indiacountries with very large populations-have performed well recently, growth has diverged significantly even using recent data. ${ }^{12}$

Moreover, the data presented in table 5 understate absolute divergence over 1960-92 because data were lacking for many low- and middle-income countries for the 1990s but not for any high-income countries. This imparts a bias toward convergence in the data similar to that pointed out by De Long (1988) regarding Baumol's (1986) finding of convergence among industrial countries. When the countries that are rich at the end are overrepresented in the sample, the sample is biased toward convergence. The growth rates of the lower three-fifths of the sample would be even lower if data were available for some of the poorly performing low- and middle-income economies in the 1990s.

Within the postwar period, this tendency toward divergence has become more pronounced with time. Easterly (2001) found that the bottom half of countries ordered by per capita income in 1980 registered zero per capita growth over 1980-98, while the top half continued to register positive growth. The reason was not a divergence in policies; policies in poor countries were converging toward those of rich countries over 1980-98.

Although many cross-economy data sets exhibit conditional convergence (Barro and Sala-i-Martin 1992), it is difficult to look at the growing differences between the rich and poor and not focus on divergence. Conditional convergence findings hold only after conditioning on an important mechanism for divergence-spillovers

11. See Lucas (1998) for an extensive discussion of this divergence, which he interprets as reflecting different takeoff times for various economies, and which he predicts will decrease as new countries take off.

12. The usual finding that initial income and growth are uncorrelated relied on data that went through 1981 or 1985, using a linear regression of growth on initial income. The use of more recent data (through 1992) and the analysis of quintiles account for this finding of absolute divergence. 
FIGURE 3. Growth Rates Diverge between Rich and Poor: 1820-1992
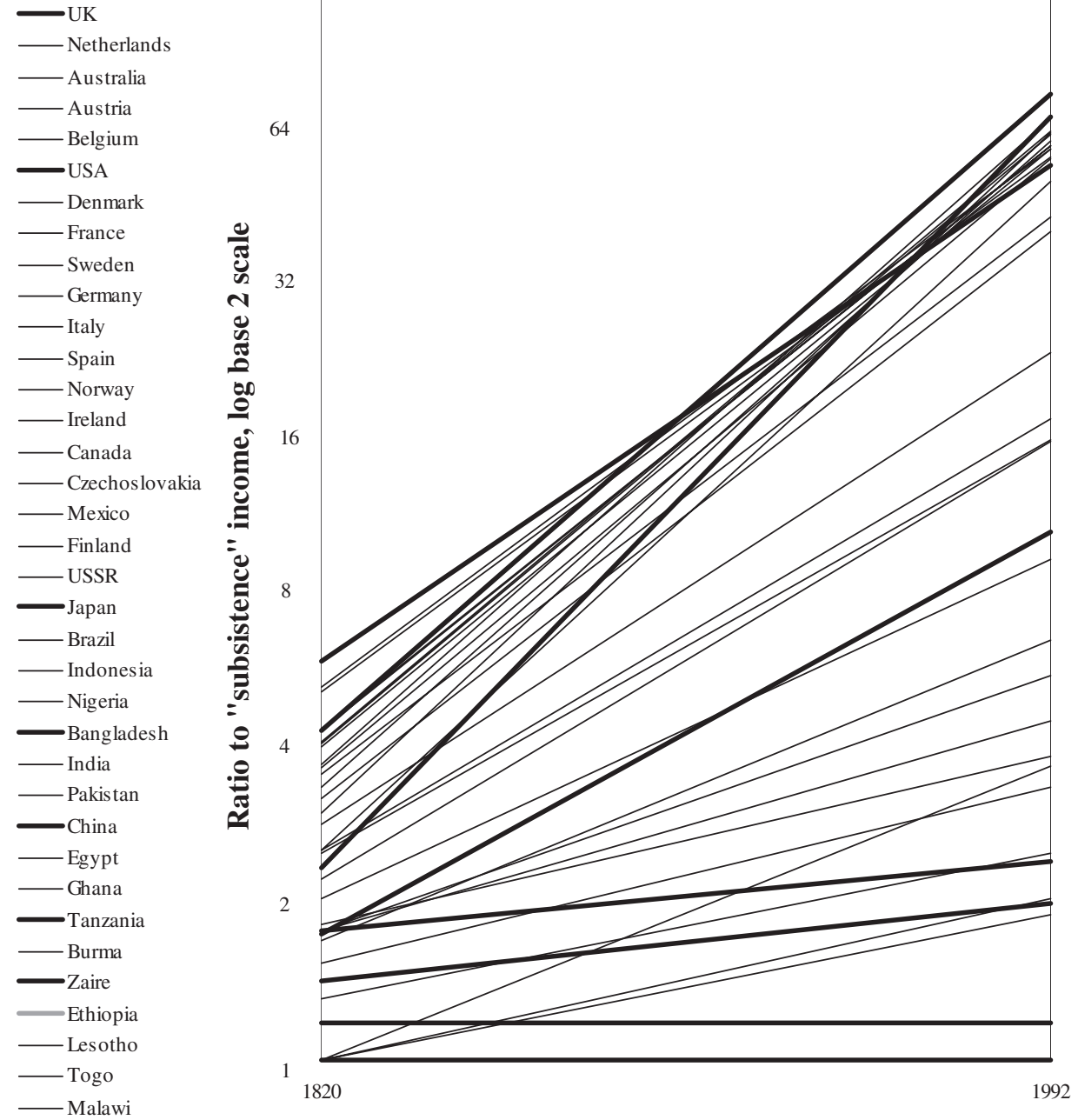

Note: Order in 1820 from richest (top) to poorest (bottom).

Source: Maddison 1995.

from the initial level of knowledge (for which conditional convergence regressions may be controlling with initial level of schooling). Conditional convergence also could follow mechanically from mean reversion (Quah 1993). Because most growth models are closed economy models, it is worth looking at what happens to convergence in closed economies. Kremer (1993) and Ades and Glaeser (1999) have found absolute divergence in the majority of closed developing economies, suggesting an "extent of the market" effect on growth in closed economies.

These findings on divergence should be seen within the context of other stylized facts. Romer (1986) shows that the growth rates of the riches countries have 
Table 5. Rich Countries Grew Rapidly, Poor Countries Slowly in 1960-92

\begin{tabular}{lc}
\hline Income quintile & $\begin{array}{c}\text { Average growth of income } \\
\text { per person, 1960-92 }(\%)\end{array}$ \\
\hline Poorest fifth of countries & 1.4 \\
Second poorest fifth of countries & 1.2 \\
Middle fifth of countries & 1.8 \\
Second richest fifth of countries & 2.6 \\
Richest fifth of countries & 2.2 \\
\hline
\end{tabular}

Note: Countries are classified by income per person in 1960 .

Source: Authors' calculations based on Summers-Heston 1991 data with subsequent on-line updates.

not slowed over the last century. King and Rebelo (1993) show that returns to capital in the United States have not been falling over the last century. Together, these observations do not naturally suggest a model that emphasizes capital accumulation and that has diminishing returns to factors, some fixed factor of production, and constant returns to scale. Neither do they provide unequivocal support for any particular conception of what best explains the something else behind these stylized facts.

\section{Stylized Fact 3. Growth Is Not Persistent, But Factor Accumulation Is}

Growth is remarkably unstable over time. The correlation of per capita growth in 1977-92 with per capita growth in 1960-76 across 135 countries is only .08. ${ }^{13}$ This low persistence is not just a characteristic of the postwar era. For the 25 countries for which there are data (Maddison 1995), the correlation between $1820-70$ and 1870-1929 is only .097.

In contrast, the cross-period correlation of growth in capital per capita is 0.41 . For models that postulate a linear relationship between growth and the share of investment in GDP (using investment share in GDP as an alternative measure of capital accumulation), the mismatch in persistence is even worse. ${ }^{14}$ The correlation of investment share in GDP in 1977-92 with investment share in 1960-76 is .85. Nor do models that postulate growth per capita as a function of human capital accumulation do better. The correlation across 1960-76 and 1977-92 for primary enrollment is .82 , while the cross-period correlation for secondary enrollment is .91 . This suggests that much of the large variation of growth over

13. Data on per capita growth are from the PWT 5.6. The low persistence of growth rates, and the high persistence of investment and education, was previously noted in Easterly and others (1993).

14. Models supposing a linear relationship between growth and investment have a long history in economics. See Easterly (1999b) for a review of the Harrod-Domar tradition that continues down to the present. For a new growth theory justification of this relationship, see McGrattan (1998). 
time is not explained by the much smaller variation in physical and human capital accumulation.

\section{Takeoff into Steady-State Growth Is Rare}

The typical model of growth, in both the old and new growth literatures, features a steady-state growth rate. Historically, this was probably inspired by the U.S. experience of remarkably steady growth of about 2 percent per capita over nearly two centuries (Jones 1995a, 1995b; Rebelo and Stokey 1995).

Because all countries must have had prior histories of stagnation, another characterization of the typical growth path is the "takeoff into self-sustained growth" (the phrase is from Rostow 1960; more recent theoretical modeling of takeoff includes Baldwin 1998, Krugman and Venables 1995, Jones 1999, Lucas 1998, and Hansen and Prescott 1998). The prevailing image is a smooth acceleration from stagnation into steady-state growth. Developing countries are supposed to have taken off beginning in the 1960s, when their growth was rapid and exceeded expectations.

Experience did not bear out the idea of steady growth beginning in the 1960s. Many countries experienced booms and crashes (Pritchett 2000, Rodrik 1998). Even when ten-year average growth rates are used, which should be long enough to iron out cyclical swings, the cross-section standard deviation is about 2.5 percentage points and the variation over time swamps the cross-section variation. In 48 of 119 countries with 20 years or more of data over 1960-97, a breakpoint can be found in which the subsequent decade's per capita growth is more than 5 percentage points-two cross-section standard deviationsabove or below the previous decade's growth. ${ }^{15}$ All of the countries with growth booms or crashes were developing countries, except for Greece and Portugal. Figure 4 illustrates the rollercoaster ride of Côte d'Ivoire, Guyana, Jamaica, and Nigeria.

Stable growth may be a better description of industrial than developing countries. Of 88 industrial and developing countries with complete data for 196097, only 12 had growth above 2 percent per capita in every decade. Half were in East Asia.

\section{Variance Decomposition over Time}

This supposition of unstable growth is further confirmed by variance decomposition exercises, with decomposition over time rather than across countries. In conjunction with the cross-country variance decomposition presented above, this analysis represents a full exploration of the panel data on growth and its factors.

A panel of seven five-year time periods was constructed for each country for per capita growth and growth in physical capital per capita. Country means are

15. Thirty-seven countries had a growth drop of 5 percentage points or more, 19 countries of 5 percentage points or more, and 8 countries were included in both groups. 
Figure 4. Examples of Variable Per Capita Income over Time: 1960-96

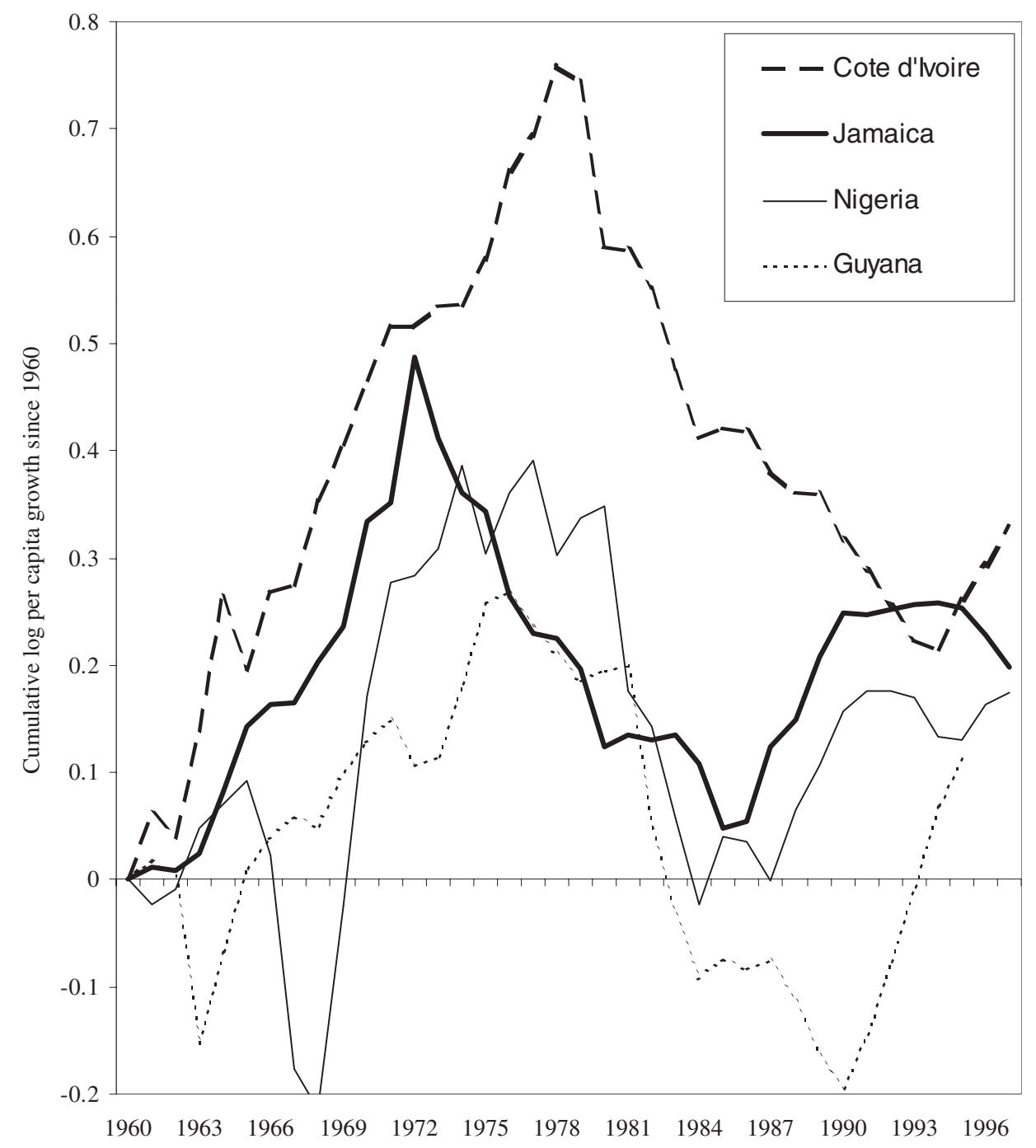

Source: World Bank data.

then subtracted and the variance is analyzed using the same formula as before (see equation 3). For the same sample of countries, TFP accounts for 86 percent of the intertemporal variation in overall growth and 61 percent of the crosssectional variation. Thus, growth is much more unstable over time than physical capital growth.

Besides emphasizing the importance of TFP in explaining long-run development patterns, the findings that growth is not persistent and that growth patterns are very different across countries complicate the challenge for economic theorists. 
Existing models miss important development experiences. Some countries grow steadily (the United States). Some grow steadily and then stop for long periods (Argentina). Some do not grow for long periods and then suddenly take off (Republic of Korea, Thailand). Others have never grown (Somalia). Accounting for these very different growth experiences will be very difficult with sole reliance on either steady-state models or standard multiple-equilibria models. Different models may be needed for different patterns of growth across countries. Steady-state models fit the U.S. type experience. Multiple equilibria models are a better fit for unstable growth cases because countries' long-run fundamentals are stable. ${ }^{16}$

\section{Stylized Fact 4. When It Rains, It Pours: All Factors Flow in the Same Direction}

This section presents new information on the concentration of economic activity, using cross-country data, data from counties in the United States, information on developing countries, and data on international flows of capital, labor, and human capital. This concentration has a fractal-like quality. It recurs at all levels of analysis, from the global to the urban. It suggests that some regions have "something" that attracts all factors of production, whereas others do not.

Better policies (legal systems, property rights, political stability, public education, infrastructure, taxes, regulations, macroeconomic stability) in one area than in another could explain these factor flows. But such policies are national; they cannot explain findings of within-country concentration (discussed below). Externalities may lead to factor congregation. Critically, policy differences, or externalities, or differences in something else do not have to be large. Small differences can have dramatic long-run implications. So, although no specific explanation is offered, the results of this analysis suggest a need for more work on economic geography as a vehicle for understanding economic growth.

\section{Concentration}

An obvious observation at the global level is that high income is concentrated among a small number of countries (see map 1). The top 20 countries have only 15 percent of world population but produce 50 percent of world GDP. The poorest

16. The nonpersistence of growth rates does not inherently contradict the stylized fact of divergence or the stylized fact that national policies influence long-run growth rates. While policies are persistent and significantly associated with long-run growth (which is not persistent), the $R^{2}$ of the growth regression is generally smaller than 0.50 . Thus, something else (besides national policies) is very important for explaining cross-country differences in long-run growth rates. In terms of divergence, the stylized fact of the nonpersistence of growth rates emphasizes that growth follows very different paths across countries and that there is a high degree of volatility. Nevertheless, there are countries that have achieved comparatively greater success over the long run. While France, Germany, and the United Kingdom have experienced growth fluctuations, they have enjoyed a steeper-and less volatile-growth path than Argentina and Venezuela, for example, whose growth paths have not only been more volatile but exhibited dramatic changes in trends. 
MaP 1. The Rich and the Poor

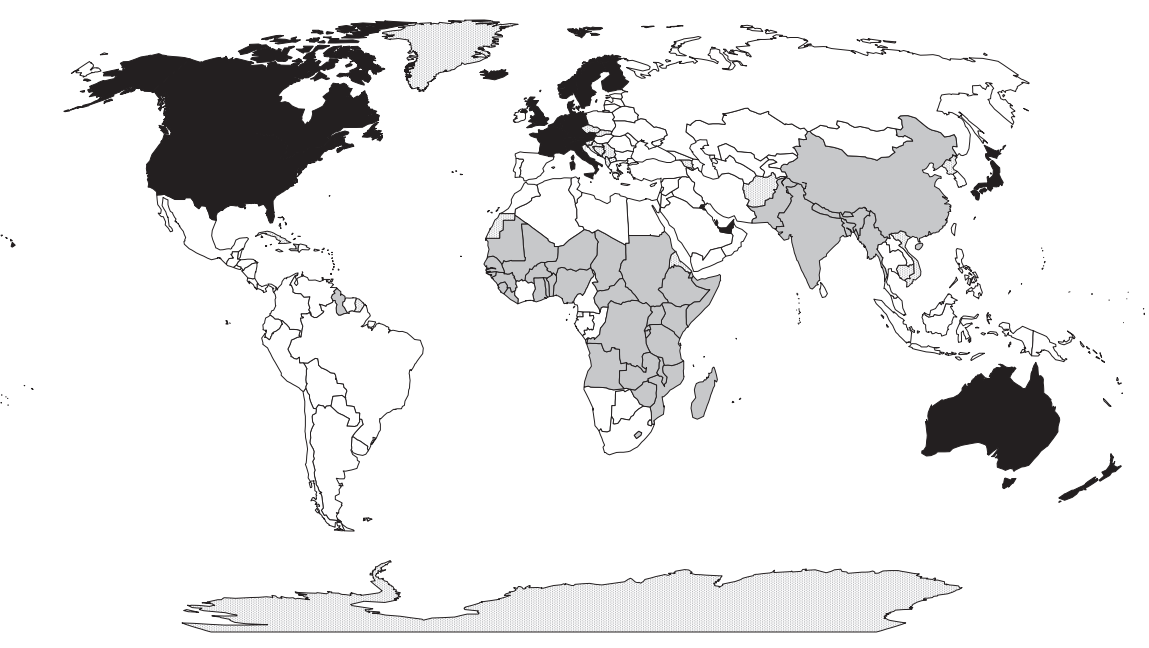

The countries in black contain 15 percent of world population but produce 50 percent of world GDP. The countries in gray contain 50 percent of world population but produce 14 percent of world GDP.

half of the world's population accounts for only 14 percent of its GDP. ${ }^{17}$ These concentrations of wealth and poverty have an ethnic and geographic dimension: 18 of the top 20 countries are in Western Europe or were settled primarily by Western Europeans; 17 of the poorest 20 countries are in tropical Africa. The richest country in 1985 (the United States) had an income 55 times that of the poorest country (Ethiopia). When inequality within countries is considered, international income differences are even starker. The income of the richest quintile in the United States was 528 times that of the poorest quintile in Guinea-Bissau.

Income is highly concentrated by area as well, as shown by data on GDP per square kilometer. The densest 10 percent of world land area accounts for 54 percent of global GDP; the least dense for only 11 percent. ${ }^{18}$

These calculations understate the degree of concentration because they assume that income is evenly spread among people and land area within countries. A more detailed look within countries also shows high concentrations of wealth and poverty.

17. These calculations omit the oil-exporting countries, in which GDP is not properly measured because all of oil extraction is treated as current income rather than asset depletion.

18. An alternative explanation would be that some land areas, accounting for a small share of the earth's surface, have a large productivity advantage. Mellinger, Sachs, and Gallup (1999) argue that temperate coastal zones have a large productivity advantage. If this were true, economic activity would be distributed fairly evenly along temperate coastal zones (adjusting for any small intrinsic differences among such zones). However, even along temperate coastal zones, casual observations would suggest high bunching of activity. 
Map 2. Densely Populated U.S. Counties

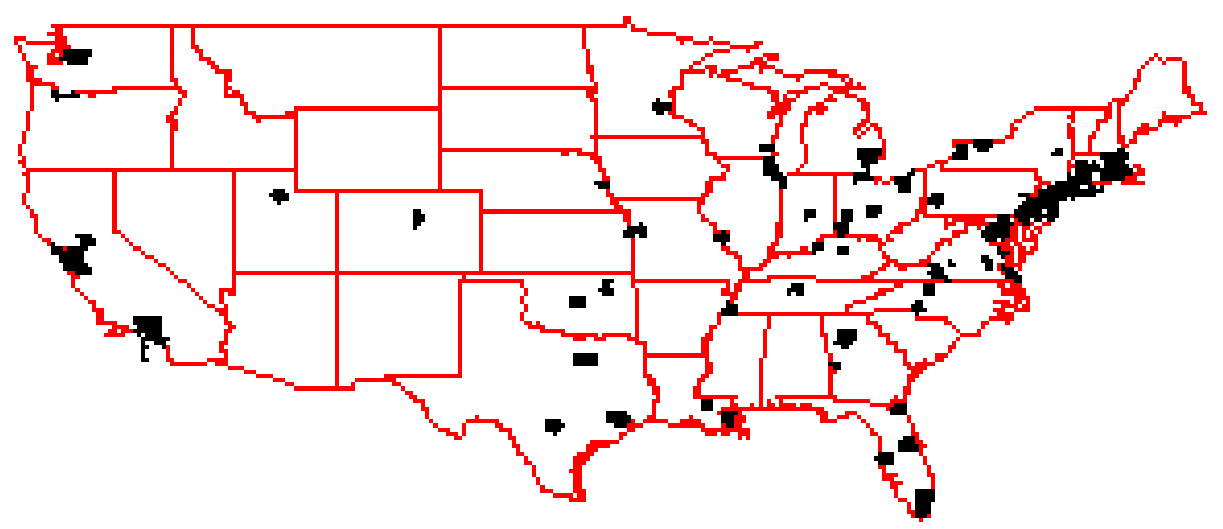

Counties shown in black take up 2 percent of U.S. land area but account for half of U.S. GDP.

Consider the United States. Data on GDP per square mile for 3,141 counties show that counties accounting for only 2 percent of the land produce 50 percent of GDP, while the least dense counties that account for 50 percent of the land produce only 2 percent of GDP (map 2 ). Nor is this finding a consequence merely of the large unsettled areas of the West and Alaska. The same calculation for land east of the Mississippi River yields similarly extreme concentration: 50 percent of GDP is produced on 4 percent of the land. The densest county is New York, New York, with a GDP per square mile of $\$ 1.5$ billion. This is about 55,000 times more than the least dense county east of the Mississippi $(\$ 27,000$ per square mile in Keweenaw, Michigan). Even this understates the degree of concentration because even the most casual empiricism will detect rich and poor areas within a given county (New York county contains Harlem as well as Wall Street).

The concentration of counties accounting for half of U.S. GDP is explained by the fact that these are metropolitan counties and most economic activity takes place in densely populated metropolitan areas. Metropolitan counties are \$3,300 richer per person than rural counties (the difference is statistically significant, with a $t$-statistic of 29). More generally, there is a strong correlation between per capita income of U.S. counties and their population density (correlation coefficient of .48 for the $\log$ of both concepts, with a $t$-statistic of 30 on the bivariate association). But concentration is high even within metropolitan counties: 50 percent of metropolitan GDP is produced in counties accounting for only 6 percent of metropolitan land area. ${ }^{19}$

There are also regional income differences between metropolitan areas. Metropolitan areas in the Boston-Washington corridor have a per capita in-

19. Metropolitan counties are those that belong to a PMSA or MSA in the census classification of counties. 
come $\$ 5,874$ higher on average than other metropolitan areas. This is a huge difference: It is equal to 2.4 standard deviations in the metropolitan area sample. Although there may be differences in the cost of living, they are unlikely to be so large as to explain this difference. (The rent component of the cost of living may reflect the productivity or the amenity advantages of the area-it seems unlikely that amenities are different enough among areas to explain these differences.)

There are other possible explanations of geographic concentration, such as inherent geographic advantages. Like Mellinger, Sachs, and Gallup (1999), Rappaport and Sachs (1999) argue that spatial concentration of activity in the United States has much to do with access to the coast. However, casual observation suggests high concentration even within coastal areas (there are sections along the Boston-Washington corridor with no radio reception). Some studies suggest that high transport costs and low congestion costs could also play a role (Krugman 1991, 1995, 1998; Fujita, Krugman, and Venables 1999). However, these studies also point to locations of particular industries (the Silicon Valley phenomenon) as evidence of other types of geographic spillover, including technology spillovers and specialized producer services with high fixed costs. And the high rents in downtown metropolitan areas suggest that congestion costs are significant. As Lucas (1988, p. 39) says, "What can people be paying Manhattan or downtown Chicago rents for, if not for being near other people?"

\section{Poor Areas}

Like wealth, poverty is also concentrated. In the United States, poverty is regionally concentrated. These concentrations have an ethnic dimension as well (see map 3). Four ethnogeographic clusters of counties have poverty rates above 35 percent:

- Counties in the West with large proportions (>35 percent) of Native Americans.

- Counties along the Mexican border with large proportions (> 35 percent) of Hispanics.

- Counties along the lower Mississippi River in Arkansas, Mississippi, and Louisiana and in the "black belt" of Alabama, all of which have large proportions of blacks (> 35 percent).

- Virtually all-white counties in the mountains of eastern Kentucky.

The county data did not pick up the well-known phenomenon of inner-city poverty, mainly among blacks, because counties that include inner cities also include rich suburbs. (An isolated example of an all-black city is East St. Louis, Illinois, which is 98 percent black and has a poverty rate of 44 percent.) Of course, poverty is concentrated in the inner city as well. An inner city ZIP code in Washington, D.C., College Heights in Anacostia, has only one-fifth of the income of a rich ZIP code in Bethesda, Maryland. This has an ethnic dimension again because College Heights is 96 percent black and the rich ZIP code in Bethesda is 96 percent white. The Washington, D.C., metropolitan area as a whole shows 
MaP 3. Poverty Traps in the U.S. County Data

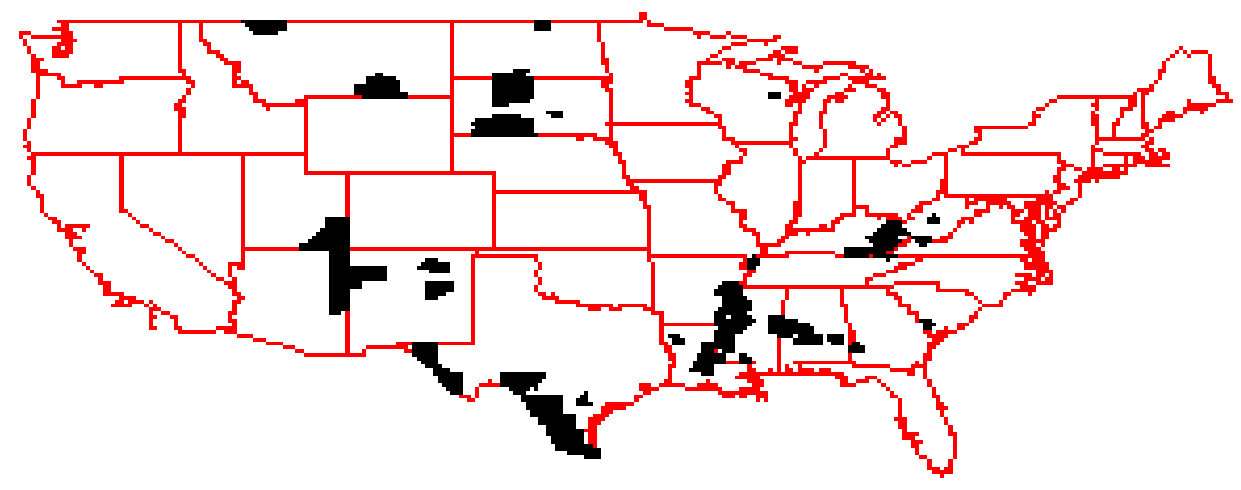

Counties in black have more than 35 percent poverty rate.

the striking East-West divide between poor and rich ZIP codes, which again roughly corresponds to the black-white ethnic divide (see map 4). ${ }^{20}$

Borjas $(1995,1999)$ suggests that strong neighborhood and ethnic externalities may help explain poverty and ethnic clusters within cities. The 1990 census tracts with the highest shares of blacks have 50 percent of the black population but only 1 percent of the white population. ${ }^{21}$ Although this segregation by race and class could simply reflect the preferences of rich white people to live next to each other, economists usually prefer to offer economic motivations rather than exogenous preferences as explanations of economic phenomena. Benabou (1993, 1996) stresses the endogenous sorting between rich and poor, so the rich can take advantage of such externalities as locally funded schools.

Poverty areas exist within many countries: northeast Brazil, southern Italy, Chiapas in Mexico, Balochistan in Pakistan, and the Atlantic Provinces in Canada. Researchers have found that externalities explain part of these poverty clusters. Bouillon, Legovini, and Lustig (1999) find a negative Chiapas effect in Mexican household income data, an effect that has worsened over time. Households in the poor region of Tangail-Jamalpur in Bangladesh earned less than households with similar characteristics in the better-off region of Dhaka (Ravallion and Wodon 1998). Ravallion and Jalan (1996) and Jalan and Ravallion (1997) likewise found that households in poor counties in southwest China earned less than households with identical human capital and other characteristics in rich Guangdong Province. Rauch (1993) found that individuals with identical characteristics earn less in low human capital cities in the United States than in high human capital cities.

20. Brookings Institution (1999) notes that this East-West geographic divide of the Washington, D.C., area shows up in many socioeconomic variables (poverty rates, free and reduced price school lunches, road spending).

21. From the Urban Institute's Underclass Database, which contains data on white, black, and "other" population numbers for 43,052 census tracts in the United States. 
MAP 4. Rich and Poor ZIP Codes in the Washington, D.C., Metropolitan Area

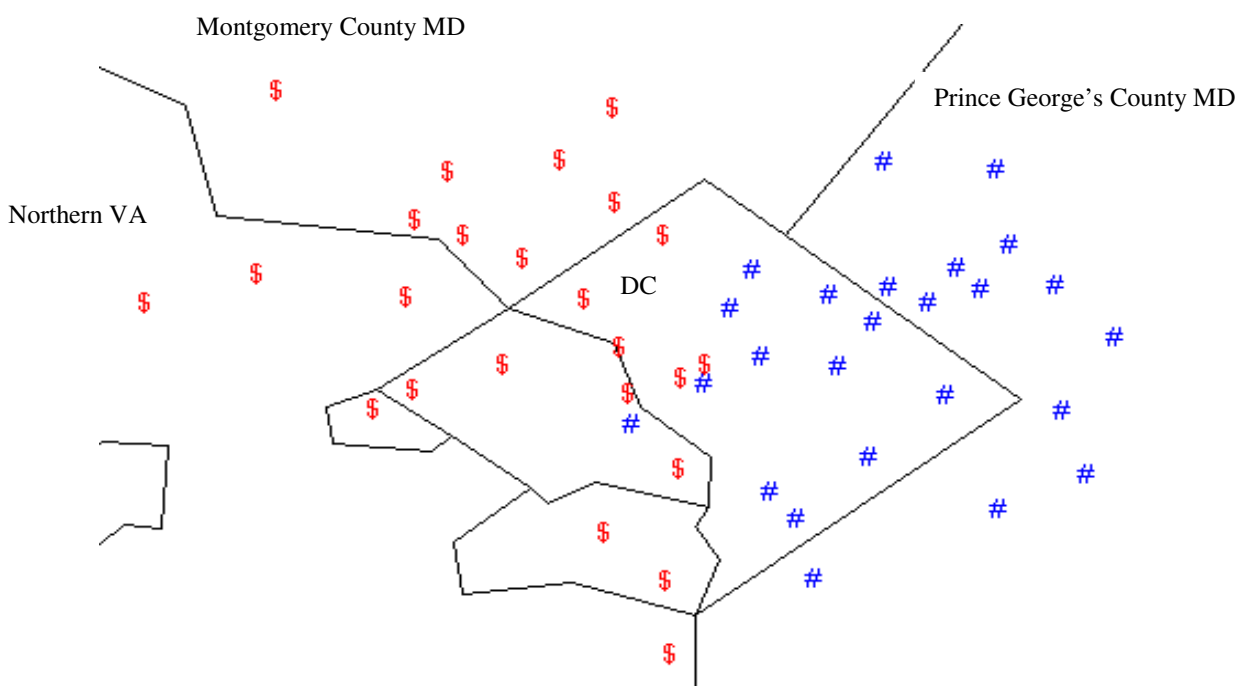

\$ indicates richest fourth of zip codes in metropolitan area; \# indicates poorest fourth.

\section{Ethnic and Related Differentials}

Some theories stress in-group externalities (Borjas 1992, 1995, 1999; Benabou 1993, 1996). Poverty and riches are also concentrated in certain ethnic groups. Exogenous savings preferences are not an appealing explanation. Discrimination and intergenerational transmission could explain ethnic differences, but for growth models the differences seem more consistent with in-group spillovers than with individual factor accumulation.

The purely ethnic differentials in the United States are well known. Asians earn 16 percent more than whites, and blacks earn 41 percent less, Native Americans 36 percent less, and Hispanics 31 percent less. ${ }^{22}$ There are also more subtle ethnic earnings differentials. Third-generation immigrants with Austrian grandparents had 20 percent higher wages in 1980 than third-generation immigrants with Belgian grandparents (Borjas 1992). Among Native Americans, the Iroquois earn almost twice the median household income of the Sioux.

Other ethnic differentials appear by religion. Episcopalians earn 31 percent more than Methodists (Kosmin and Lachman 1993, p. 260). Of the Forbes 400 richest Americans, 23 percent are Jewish, although only 2 percent of the U.S. population is Jewish (Lipset 1997). ${ }^{23}$

22. Tables 52 and 724, 1995 Statistical Abstract of the United States (United States Government 1996).

23. Ethnic differentials are also common in other countries. The ethnic dimension of rich trading elites is well known-the Lebanese in West Africa, the Indians in East Africa, and the overseas Chinese in Southeast Asia. Virtually every country has its own ethnographic group noted for their success. For 
In Latin America, the main ethnic divide is between indigenous and nonindigenous populations (table 6). But even within indigenous groups, there are ethnic differentials. For example, there are four main language groups among Guatemala's indigenous population. Patrinos (1997) shows that the Quichespeaking indigenous groups earn 22 percent less on average than Kekchispeaking groups.

For Africa, there are numerous anecdotes about income differentials between ethnic groups, but little hard data. An exception is South Africa, where whites have 9.5 times the income of blacks. More surprisingly, among all-black traditional authorities (an administrative unit something like a village) in the state of KwaZulu-Natal, the richest traditional authority has 54 times the income of the poorest (Klitgaard and Fitschen 1997).

\section{Factor Movement}

Factor movement toward the richest areas reinforces the concentration of economic activity. Each factor of production flows to where it is already abundant.

Labor migration is overwhelmingly toward the richest countries. The three richest countries alone (the United States, Canada, and Switzerland) receive half the net immigration of all countries reporting net immigration. Countries in the richest quintile are all net recipients of migrants. Only 8 of the 90 countries in the bottom four-fifths of the sample are net recipients of migrants. Barro and Sala-i-Martin (1995, pp. 403-10) find that migration goes from poorer to richer regions in samples of U.S. states, Japanese prefectures, and European regions.

Migration also goes from sparsely populated to densely populated areas. There is a statistically significant correlation of .20 between the immigration rate of U.S. counties from 1980 to 1990 and population density in 1980. Labor flowed to areas where it was already abundant. Migration goes from poor to rich counties, with a statistically significant correlation of .21 between initial income and immigration rate (confirming the Barro and Sala-i-Martin 1995 finding for U.S. states). These two findings are related, as there is a significant positive correlation between population density and per capita income across counties. ${ }^{24} \mathrm{~A}$ regression of the immigration rate for $1980-90$ by county on population density in 1980 and income per capita in 1980 finds both to be highly significant. ${ }^{25}$

Embodied in this flow of labor are flows of human capital toward rich countries, the famous "brain drain." In the poorest fifth of countries, the probability of emigrating to the United States is 3.4 times higher for an educated person than

example, in The Gambia a tiny indigenous ethnic group called the Serahule is reported to dominate business out of all proportion to their numbers. In Zaire, Kasaians have been dominant in managerial and technical jobs since the days of colonial rule (New York Times, 9/18/1996).

24. Ciccone and Hall (1996) have a related finding for U.S. states.

25. The $t$-statistics are 8.2 for the log of population density in 1980 and 8.9 for the log of per capita income in 1979. The equation has an $R^{2}$ of .065 and has 3,133 observations. The county data are from Alesina, Baqir, and Easterly (1999). 
TABle 6. Poverty Rate Differential among Indigenous and Nonindigenous Groups in Selected Latin American Countries

\begin{tabular}{lcc}
\hline Country & Indigenous groups & Nonindigenous groups \\
\hline Bolivia & 64.3 & 48.1 \\
Guatemala & 86.6 & 53.9 \\
Mexico & 80.6 & 17.9 \\
Peru & 79.0 & 49.7 \\
\hline
\end{tabular}

Source: Psacharopoulos and Patrinos 1994 (p. 6).

for an uneducated person (based on data from Grubel and Scott 1977). Because education and income are strongly and positively correlated, human capital is flowing to where it is already abundant-the rich countries.

Carrington and Detragiache (1998) found that in 51 of 61 developing countries in their sample, people with a university education were more likely to emigrate to the United States than people with a secondary education. In all 61 countries, migration rates to the United States were lower for people with a primary education or less than for people with a secondary or university education. Lower bound estimates for the highest rates of emigration by those with university education range as high as 77 percent (Guyana), with rates of 59 percent for The Gambia, 67 percent for Jamaica, and 57 percent for Trinidad and Tobago. ${ }^{26}$ None of the emigration rates for the primary or less educated exceeds 2 percent.

The disproportionate weight of the skilled population in U.S. immigration may reflect U.S. policy. However, Borjas (1999) notes that U.S. immigration policy has tended to favor unskilled labor with family connections in the United States rather than skilled labor. In the richest fifth of countries, moreover, the probability is roughly the same that educated and uneducated will emigrate to the United States. Borjas, Bronars, and Trejo (1992) also find that the more highly educated are more likely to migrate within the United States than the less educated. ${ }^{27}$

Capital also flows mainly to areas that are already rich, as Lucas (1990) famously pointed out. In 1990, the richest 20 percent of world population received 92 percent of gross portfolio capital inflows, whereas the poorest 20 percent received 0.1 percent. The richest 20 percent of the world population received 79 percent of foreign direct investment, and the poorest 20 percent received 0.7 percent. Altogether, the richest 20 percent of the world population received 88 percent of gross private capital gross inflows, and the poorest 20 percent received 1 percent.

26. Note these are all small countries. Carrington and Detragiache (1998) point out that U.S. immigration quotas are less binding for small countries, because with some exceptions the legal immigration quota is 20,000 per country regardless of population size.

27. Casual observation suggests "brain drain" within countries. The best lawyers and doctors congregate within a few metropolitan areas like New York, where skilled doctors and lawyers are abundant, while poorer areas have difficulty attracting the top-drawer professionals. 


\section{Skill Premia and Human Capital}

Skilled workers earn less, rather than more, in poor countries. This seems inconsistent with the open economy version of the neoclassical factor accumulation model by Barro and others (1995). In the Barro and others model, capital flows equalize the rate of return to physical capital across countries, while human capital is immobile. Immobile human capital explains the difference in per worker income across countries. As Romer (1995) points out, this implies that both the skilled wage and the skill premium should be much higher in poor countries than in rich countries. To illustrate, specify a standard production function for country $i$ :

$$
Y_{i}=A K_{i}^{\alpha} L_{i}^{\beta} H_{i}^{1-\alpha-\beta} .
$$

Assuming that technology $(A)$ is the same across countries and that rates of return to physical capital are equated across countries, the ratio of the skilled wage in country $i$ to that in country $j$ is a function of their per capita incomes:

$$
\frac{\frac{\partial Y_{i}}{\partial H_{i}}}{\frac{\partial Y_{j}}{\partial H_{j}}}=\left[\frac{Y_{i} / L_{i}}{Y_{j} / L_{i}}\right]^{\frac{-\beta}{1-\alpha-\beta}} .
$$

On the basis of the physical (.3) and human capital shares (.5) suggested by Mankiw (1995), skilled wages should be five times greater in India than in the United States (to correspond to a 14 -fold difference in per capita income). In general, equation 12 shows that skilled wages differences across countries should be inversely related to per capita income if human capital abundance explains income differences across countries, as in the Barro and others model. The skill premium should be 70 times higher in India than in the United States. If the ratio of skilled to unskilled wages is about 2 in the United States, the ratio should be 140 in India. This would imply an astonishing rate of return to education70 times larger than in the United States.

The facts do not support these predictions. Skilled workers earn more in rich countries. Fragmentary data from wage surveys show that engineers average \$55,000 in New York and \$2,300 in Bombay (Union Bank of Switzerland 1994). Far from being 5 times higher in India than in the United States, skilled wages are 24 times higher in the United States than in India. The higher wages across all occupational groups are consistent with greater technological progress $(A)$ in the United States than in India. The skilled wage (proxied by salaries of engineers, adjusted for purchasing power) is positively associated with per capita income across countries, as a productivity explanation of income differences would imply (figure 5), and not negatively correlated, as a Barro and others model of human capital explanation would imply. The correlation between skilled wages and per capita income across 44 countries is .81 . 
Within India, engineers earn only about three times what building laborers earn. Rates of return to education are also only about twice as high in low-income countries (11 percent) as in high-income countries (6 percent; Psacharopolous 1994, p. 1332) -not 42 times higher. Consistent with this evidence, the flow of human capital is toward rich countries, despite barriers to immigration.

\section{Evaluating Growth Models in Light of Income Concentration}

The high concentration of income, reinforced by the flow of all factors toward the richest areas, is inconsistent with the neoclassical growth model. The distribution of income across space and across people at all levels is highly skewed to the right (skewness coefficient of 2.58 across countries in 1980, 2.2 across U.S. cities, and 1.6 across U.S. counties in 1990, where 0 is symmetry). There is no reason to think that the determinants of income in the neoclassical model (saving, population growth) are skewed to the right, but models of technological complementarities (see, for example, Kremer 1993) can explain the skewness.

Moreover, the concentration of factors in rich, densely populated areas even within countries is incompatible with a version of the neoclassical model that

Figure 5. Skilled Real Wage and Per Capita Income across Countries

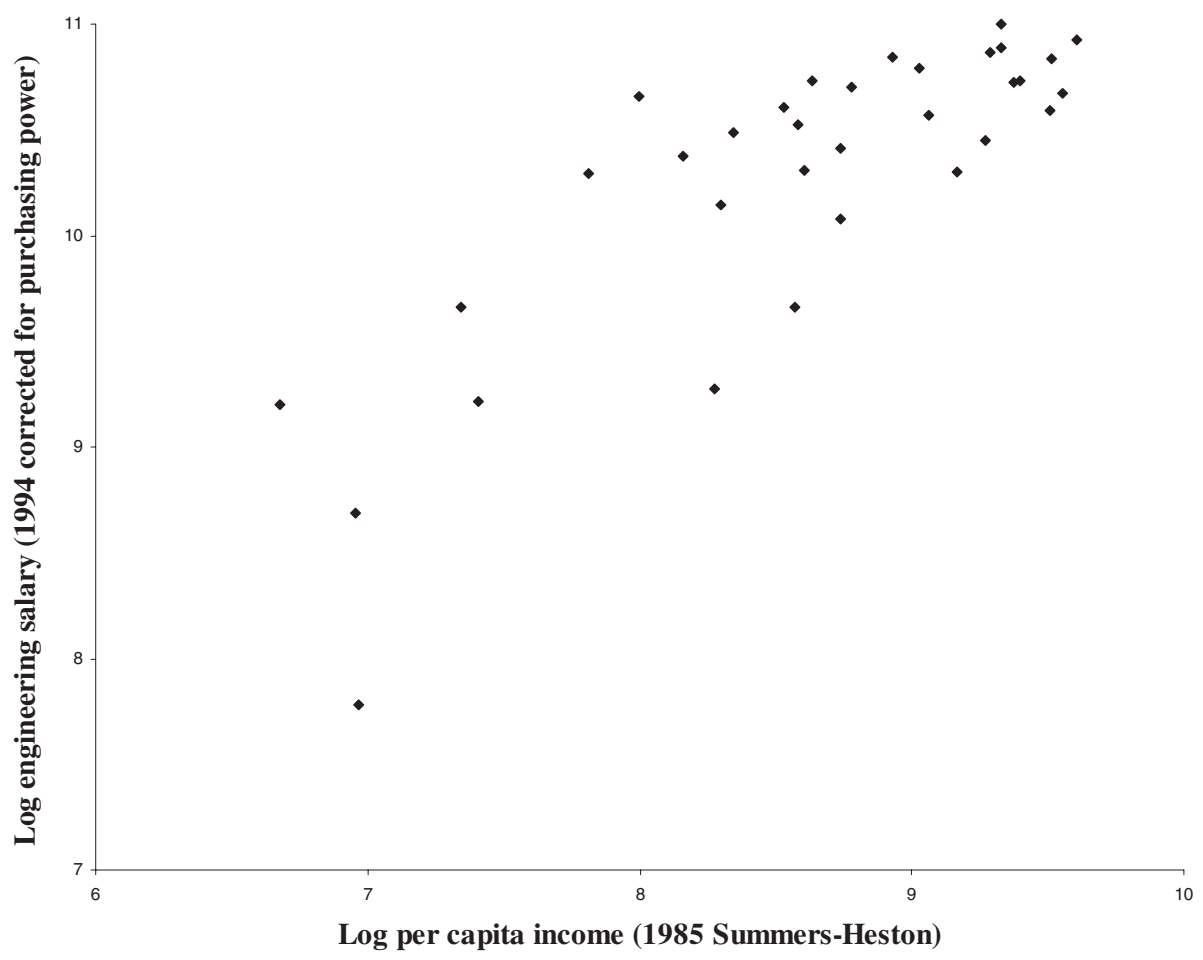

Source: Authors' calculations based on Summers and Heston for per capita income and Union Bank of Switzerland for engineering salaries. 
includes land as a factor of production. With land in fixed supply, physical and human capital and labor should all flow to areas abundant in land (adjusting for land quality) but scarce in other factors.

Furthermore, in the neoclassical model of Mankiw, Romer, and Weil (1992), physical and human capital should also flow from rich to poor areas, and unskilled labor from poor to rich. But as this study shows, physical and human capital flow toward rich areas, as does unskilled labor, though it is less mobile.

Stylized fact 4 is in harmony with Klenow and Rodriguez-Clare (1997b), who complain that the "neoclassical revival in growth economics" has "gone too far." The neoclassical model does not explain why wealth and poverty are concentrated in certain regions within countries or why there are such pronounced income differences between ethnic groups. Stylized fact 4 is consistent with poverty trap models (Azariadis and Drazen 1990, Becker, Murphy, and Tamura 1990, Kremer 1993, Murphy, Shleifer, and Vishny 1989); with models of ingroup ethnic and neighborhood externalities (Borjas 1992, 1995, 1999, Benabou 1993, 1996), and with models of geographic externalities (Krugman 1991, 1995, 1998, Fujita, Krugman, and Venables 1999).

Stylized fact 4 also seems to be more consistent with a productivity explanation of income differences than with a factor accumulation story. If a rich area is rich because technology $(A)$ is more advanced, then all factors of production will tend to flow toward this rich area, reinforcing the concentration. Spillovers between agents also seem more natural with technological models of growth, as technological knowledge is inherently more nonrival and nonexcludable than factor accumulation. Technological spillovers between agents will lead to endogenous matching of rich agents with each other, and those matches will reinforce the matching of poor people with other poor people (as in the O-ring story of Kremer [1993] or the inequality model of Benabou [1996]). A better understanding of economic geography and externalities would help shape more realistic models of economic growth.

\section{Stylized Fact 5. Policy Matters}

The empirical literature on national policies and economic growth is huge. There is considerable disagreement about which policies are most strongly linked with economic growth. Some analysts focus on openness to international trade (Frankel and Romer 1999), some on fiscal policy (Easterly and Rebelo 1993), some on financial development (Levine, Loayza, and Beck 2000), and some on macroeconomic policies (Fischer 1993). All these studies have at least one feature in common: They all find that some indicator of national policy is strongly linked with economic growth, confirming the argument made by Levine and Renelt (1992).

Most empirical assessments of the growth-policy relationship are plagued by three shortcomings. First, most do not confront endogeneity. Even when instrumental variables are used, studies frequently assume that many of the regressors are exogenous and focus only on the potential endogeneity of one variable of 
interest. This failure to fully confront causality may produce biased assessments. Second, traditional cross-country regressions may suffer from omitted variable bias. That is, cross-country growth regressions may omit an important countryspecific effect and thereby produce biased coefficient estimates. Third, almost all cross-country regressions included lagged real per capita GDP as a regressor. Because the dependent variable is the growth rate of real per capita GDP, this specification may produce biased coefficient estimates.

This study uses recent econometric techniques to examine the links between economic growth and a range of national policies. These new techniques ameliorate these potential biases so that more accurate inferences can be drawn about the impact of national policies on economic growth. The goal is not to identify the most important policies influencing growth; it is to compile key stylized facts associated with long-run growth.

Use of the latest econometric techniques (see appendix) confirms earlier findings that national policies are strongly linked with economic growth. The regression results are consistent with policies having significant long-run effects on national growth rates or on steady-state levels of national output. The regression results also show that national policies are strongly linked with TFP growth (Beck, Levine, and Loayza 2000).

The relationship between the exogenous component of national policies and economic growth is assessed using a set of conditioning information and policy indicators suggested by theory and past empirical work. Specifically, the initial level of real income per capita is included to control for convergence. The standard neoclassical growth model predicts convergence to the steady-state output per person ratio (Barro and Sala-i-Martin 1995). The coefficient on initial income does not necessarily capture only neoclassical transitional dynamics. In technology diffusion models, initial income may proxy for the initial gap in TFP between economies. In these models, therefore, catch-up can be in TFP as well as in traditional factors of production. Average years of schooling was included as an indicator of the human capital stock in the economy. Its inclusion can help in controlling for differences in steady-state levels of human capital (Barro and Sala-i-Martin 1992). Also, schooling may directly influence economic growth (Lucas 1988).

Five policy indicators were used. The inflation rate and the ratio of government expenditures to GDP were included as indicators of macroeconomic stability (Easterly and Rebelo 1993, Fischer 1993). Exports plus imports as a share of GDP and the black market exchange rate premium were included to capture degree of openness (Frankel and Romer 1999). Financial intermediary credit to the private sector as a share of GDP was included as a measure of financial intermediary development (Levine, Loayza, and Beck 2000). There is no attempt to suggest that these are the most important policy indicators. They are used only to assess whether economic growth is strongly linked with these national policy indicators after controlling for endogeneity and other biases in existing empirical work.

As in much of the cross-country literature, the regression results show evidence of conditional convergence (table 7). Specifically, contingent of the level 
of human capital, poorer countries tend to grow faster than richer countries as each country converges toward its steady-state. This finding is consistent with a major implication of the textbook neoclassical growth model. The regression also shows that greater human capital—as measured by average years of schooling of the working age population-is associated with faster economic growth. Moreover, since the GMM panel estimator controls for endogeneity, this finding suggests that the exogenous component of schooling exerts a positive impact on economic growth. These results are consistent with models that focus on factor accumulation or on TFP growth.

The results are consistent with-but not proof of-long-run growth effects of national policies, which is consistent with an endogenous productivity growth model. In contrast, models that feature only transitional factor accumulation dynamics usually predict weaker policy effects on growth than endogenous productivity growth models. Furthermore, complementary work in Beck, Levine, and Loayza (2000) suggests a powerful connection between national policies and TFP growth. The exogenous components of international openness-as measured

Table 7. Economic Growth and National Policies

\begin{tabular}{|c|c|}
\hline Variable & Result \\
\hline Constant & $\begin{array}{c}0.082 \\
(0.875)\end{array}$ \\
\hline Initial income per capita ${ }^{a}$ & $\begin{array}{c}-0.496 \\
(0.001)\end{array}$ \\
\hline Average years of schooling ${ }^{b}$ & $\begin{array}{c}0.950 \\
(0.001)\end{array}$ \\
\hline Openness to trade ${ }^{a}$ & $\begin{array}{c}1.311 \\
(0.001)\end{array}$ \\
\hline Inflation $^{\mathrm{b}}$ & $\begin{array}{c}0.181 \\
(0.475)\end{array}$ \\
\hline Government size ${ }^{\mathrm{a}}$ & $\begin{array}{l}-1.445 \\
(0.001)\end{array}$ \\
\hline Black market premium ${ }^{b}$ & $\begin{array}{c}-1.192 \\
(0.001)\end{array}$ \\
\hline Private credit $^{\mathrm{a}}$ & $\begin{array}{c}1.443 \\
(0.001)\end{array}$ \\
\hline Sargan test ${ }^{\mathrm{c}}(p$-value $)$ & 0.506 \\
\hline Serial correlation test ${ }^{\mathrm{d}}(p$-value $)$ & 0.803 \\
\hline
\end{tabular}

Note: Numbers in parentheses are $p$-values. The dependent variable is real per capita GDP growth.

ancluded as $\log$ (variable).

bIncluded as $\log (1+$ variable $)$.

cThe null hypothesis is that the instruments used are not correlated with the residuals.

dThe null hypothesis is that the errors in the first-difference regression exhibit no second-order serial correlation.

Source: Authors's calculations based on analyses in Beck, Levine, and Loayza (2000). 
by the ratio of trade to GDP and by black market exchange rate premia-are significantly correlated with economic growth.

Macroeconomic policy is also important. Large government tends to hurt economic growth, although inflation does not enter significantly. A higher black market exchange rate premium exerts a negative impact on growth. More international trade tends to boost economic growth. While considerable research suggests a negative link between inflation and economic performance (Bruno and Easterly 1998), recent research suggests that inflation is strongly linked with financial development (Boyd, Levine, and Smith 2001). Thus, it may not enjoy an independent link with growth when financial development is controlled for. Finally, a higher level of financial development boosts economic growth. In sum, national policies are strongly linked with economic growth.

\section{Conclusion}

The major empirical regularities of economic growth emphasize the role of something else besides factor accumulation. The TFP residual accounts for most of the cross-country and cross-time variation in growth. Income across countries diverges over the long run, while the growth rates of the rich are not slowing and returns to capital are not falling. This observation is less consistent with simple models that feature diminishing returns, factor accumulation, some fixed factor of production, and constant returns to scale and more consistent with the observation that something else is important for explaining long-run economic success. Growth is highly unstable over time, whereas factor accumulation is more stable, which certainly emphasizes the role of something else in explaining variations in economic growth. All factors of production flow to the richest areas, suggesting that they are rich because of high $A$ rather than high $K$. Divergence of per capita incomes and the concentration of economic activity suggest that technology has increasing returns. Finally, national policies are strongly linked with long-run economic growth rates.

Nothing in this study argues that factor accumulation is unimportant in general or denies that it is critically important for some countries at specific junctures. TFP does not explain everything, everywhere, always. Rather, the study shows that something else-besides factor accumulation-plays a prominent role in explaining differences in economic performance across countries.

More research is needed on the "residual" determinants of growth and income, such as technology and externalities. There is little doubt that technology is a formidable force. Nordhaus (1994) estimates that 1 Btu of fuel consumption today buys 900 times more lighting (measured in lumen hours) than it did in 1800. Over the past two decades, computing power per dollar invested has risen by a factor of 10,000, and the cost of sending information over optical fiber has fallen by a factor of 1,000 (World Bank 1999, pp. 5 and 57). Just from 1991 to 1998 , the price of a megabyte of hard disk storage fell from $\$ 5$ to $\$ 0.03 .{ }^{28}$ 
Not every technology has improved at this speed of course. But Mokyr (1992) was right to call technology "the lever of riches."

\section{Appendix: Econometric Methodology}

A generalized method of moments (GMM) dynamic panel estimator was used to assess the relationship between policy and economic growth. Panel data for 73 countries over the period 1960-95 were averaged over seven nonoverlapping five-year periods.

Consider the following equation:

$$
y_{i, t}-y_{i, t-1}=(\alpha-1) y_{i, t-1}+\beta^{\prime} X_{i, t}+\eta_{i}+\varepsilon_{i, t}
$$

where $y$ is the logarithm of real per capita GDP, $X$ is the set of explanatory variables (other than lagged per capita GDP), $\eta$ is an unobserved country-specific effect, $\varepsilon$ is the error term, and the subscripts $i$ and $t$ represent country and time period. Time dummy variables were also included to account for time-specific effects.

Equation 13 can be rewritten as:

$$
y_{i, t}=\alpha y_{i, t-1}+\beta^{\prime} X_{i, t}+\eta_{i}+\varepsilon_{i, t} .
$$

First differences of equation 14 are taken to eliminate the country-specific effect:

$$
y_{i, t}-y_{i, t-1}=\alpha\left(y_{i, t-1}-y_{i, t-2}\right)+\beta^{\prime}\left(X_{i, t}+X_{i, t-1}\right)+\left(\varepsilon_{i, t}-\varepsilon_{i, t-1}\right) .
$$

The use of instruments is required to deal with the correlation, by construction, of the new error term $\varepsilon_{i, t}-\varepsilon_{i, t-1}$ with the lagged dependent variable $y_{i, t-1}-y_{i, t-2}$ and with the likely endogeneity of the explanatory variables. Under the tested assumptions that the error term $(\varepsilon)$ is not serially correlated and the explanatory variables $(X)$ are weakly exogenous (the explanatory variables are assumed to be uncorrelated with future realizations of the error term), appropriately lagged values of the regressors can be used as instruments, as specified in the following moment conditions:

$$
\begin{aligned}
E\left[y_{i, t-s} \cdot\left(\varepsilon_{i, t}-\varepsilon_{i, t-1}\right)\right]=0 & \text { for } s \geq 2 ; t=3, \ldots, T \\
E\left[X_{i, t-s} \cdot\left(\varepsilon_{i, t}-\varepsilon_{i, t-1}\right)\right]=0 & \text { for } s \geq 2 ; t=3, \ldots, T .
\end{aligned}
$$

The GMM estimator based on these conditions is referred to as the difference estimator.

There are, however, conceptual and statistical shortcomings with this difference estimator. It eliminates the cross-country relationship between national policies and per capita GDP growth, which is of conceptual interest. Statistically, when the regressors in equation 15 are persistent, lagged levels of $X$ and $y$ are weak instruments. Instrument weakness influences the asymptotic and small-sample performance of the difference estimator. Asymptotically, the variance of the coefficients rises. In small samples, weak instruments can produce biased coefficients.

To reduce the potential biases and imprecision associated with the usual difference estimator, Arellano and Bover (1995) and Blundell and Bond (1997) 
develop a system of regressions in differences and levels. The instruments for the regression in differences are the same as those above. The instruments for the regression in levels are the lagged differences of the corresponding variables. These are appropriate instruments under the following additional assumption: although there may be correlation between the levels of the right-hand-side variables and the country-specific effect in equation 14 , there is no correlation between the differences of these variables and the country-specific effect. This assumption results from the following stationarity property:

$$
\begin{gathered}
E\left[y_{i, t+p} \cdot \eta_{i}\right]=E\left[y_{i, t+q} \cdot \eta_{i}\right] \\
\text { and } E\left[X_{i, t+p} \cdot \eta_{i}\right]=E\left[X_{i, t+q} \cdot \eta_{i}\right] \text { for all } p \text { and } q .
\end{gathered}
$$

The additional moment conditions are.

$$
\begin{array}{cl}
E\left[\left(y_{i, t-s}-y_{i, t-s-1}\right) \cdot\left(\eta_{i}+\varepsilon_{i, t}\right)\right]=0 & \text { for } s=1 \\
E\left[\left(X_{i, t-s}-X_{i, t-s-1}\right) \cdot\left(\eta_{i}+\varepsilon_{i, t}\right)\right]=0 & \text { for } s=1 .
\end{array}
$$

Thus the moment conditions presented in equations 16, 17, 19, and 20 are used with a GMM estimator to generate consistent and efficient parameter estimates.

Consistency of the GMM estimator depends on the validity of the instruments. To address this issue two specification tests were considered, as suggested by Arellano and Bond (1991), Arellano and Bover (1995), and Blundell and Bond (1997). The first is a Sargan test of overidentifying restrictions to test the overall validity of the instruments by analyzing the sample analog of the moment conditions used in the estimation. The second test examines the hypothesis that the error term $\varepsilon_{i, t}$ is not serially correlated. In both the difference regression and the system regression the differenced error term is tested for second-order serial correlation (by construction, the differenced error term is probably firstorder serially correlated even if the original error term is not). This system estimator is used to assess the impact of policies on economic growth. In addition to the system estimator, the analyses use purely cross-section, ordinary least squares regressions with one observation per country, the pure different estimator described above, and the panel estimator with only the level component of the system estimator. All yield similar results and parameter values (Levine, Loayza, and Beck 2000).

\section{REFERENCES}

Ades, Alberto, and Edward Glaeser. 1999. "Evidence on Growth, Increasing Returns, and the Extent of the Market." Quarterly Journal of Economics 114(3):1025-46.

Aghion, P., and P. Howitt. 1998. Endogenous Growth Theory. Cambridge, Mass.: MIT Press.

Alesina, Alberto, Reza Baqir, and William Easterly. 1999. "Public Goods and Ethnic Divisions." Quarterly Journal of Economics 114(4):1243-84. 
Arellano, Manuel, and Bond, Stephen. "Some Tests of Specification for Panel Data. Monte Carlo Evidence and an Application to Employment Equations." Review of Economic Studies 58(2):277-97.

Arellano, Manuel, and Bover, Olympia. 1995. "Another Look at the Instrumental-Variable Estimation of Error-Components Models." Journal of Econometrics 68(1):29-52.

Azariadis, Costas, and Allan Drazen. 1990. "Threshold Externalities in Economic Development," Quarterly Journal of Economics 105:501-26.

Bairoch, Paul. 1993. Economics and World History: Myths and Paradoxes. Chicago: University of Chicago Press.

Baldwin, Richard E. 1998. "Global Income Divergence, Trade and Industrialization. The Geography of Growth Take-offs.” NBER Working Paper Series No. 6458.1. NBER, Washington, D.C.

Bank for International Settlements. 1996. 66th Annual Report. BIS, Basel.

Barro, Robert, and Xavier Sala-i-Martin. 1992. "Convergence." Journal of Political Economy 100(2):223-51.

- 1995. Economic Growth. New York: McGraw-Hill.

Barro, Robert, J. Mankiw, N. Gregory, and X. Sala-i-Martin. 1995. "Capital Mobility in Neoclassical Models of Growth." American Economic Review 85:103-15.

Baumol, William J. 1986. "Productivity Growth, Convergence, and Welfare. What the Long Run Data Show.” American Economic Review 76(5):1072-85.

Beck, Thorsten. Ross Levine, and Norman Loayza. 2000. "Finance and the Sources of Growth." Journal of Financial Economics 58(1-2):261-300.

Becker, Gary S., Kevin M. Murphy, and Robert Tamura. 1990. "Human Capital, Fertility, and Economic Growth." Journal of Political Economy 98(5):S12-S37.

Benabou, Roland. 1993. "Workings of a City. Location, Education, and Production." Quarterly Journal of Economics 108:619-52.

- 1996. "Heterogeneity, Stratification, and Growth. Macroeconomic Implications of Community Structure and School Finance.” American Economic Review 86(3):584609.

Benhabib. J., and M. Spiegel. 1994. "Role of Human Capital in Economic Development. Evidence from Aggregate Cross-Country Data." Journal of Monetary Economics $34: 143-73$.

Bils, Mark, and P. Klenow. 1996. "Does Schooling Cause Growth?” American Economic Review 90(5.):1160-83.

Blomstrom, Magnus, R. Lipsey, and M. Zejan. 1996. "Is Fixed Investment the Key to Economic Growth?" Quarterly Journal of Economics 111(1):269-76.

Blundell, Richard, and Bond, Stephen. 1997. "Initial Conditions and Moment Restrictions in Dynamic Panel Data Models." University College London Discussion Paper 97-07.

Borjas, George J. 1992. "Ethnic Capital and Intergenerational Mobility." Quarterly Journal of Economics 107:123-50.

—. 1995. "Ethnicity, Neighborhoods, and Human Capital Externalities." American Economic Review 85(3):365-90.

-1999. Heaven's Door. Immigration Policy and the American Economy. Princeton, N.J.: Princeton University Press.

Borjas, George J., Stephen G. Bronars, and Stephen J. Trejo. 1992. "Self Selection and Internal Migration in the United States." Journal of Urban Economics 32:159-85. 
Bouillon, César, Arianna Legovini, and Nora Lustig. 1999. "Rising Inequality in Mexico, Returns to Household Characteristics and the 'Chiappas' Effect." Inter-American Development Bank, mimeo.

Boyd, John H., Ross Levine, Bruce D. Smith. 2001. "The Impact of Inflation on Financial Sector Performance." Journal of Monetary Economics. Forthcoming.

Brookings Institution Center on Urban and Metropolitan Policy. 1999. A Region Divided. The State of Growth in Greater Washington. Washington, D.C.: Brookings Institution.

Bruno, Michael, and Easterly, William. 1998. "Inflation Crises and Long-run Growth.” Journal of Monetary Economics 41:3-26.

Burnside, Craig. 1996. "Production Function Regressions, Returns to Scale and Externalities." Journal of Monetary Economics 37:177-200.

Carrington, William J., and Enrica Detragiache. 1998. "How Big Is the Brain Drain?" International Monetary Fund Working Paper 98/102.

Carroll, C. D., and D. N. Weil. 1993. "Saving and Growth. A Reinterpretation.” CarnegieRochester Series on Public Policy.

Ciccone, Antonio, and Robert E. Hall. 1996. "Productivity and the Density of Economic Activity." American Economic Review 86(1):54-70.

Collier, Paul, David Dollar, and Nicholas Stern. 2000. "Fifty Years of Development." World Bank, mimeo.

Costello, Donna M. 1993. "Cross-Country, Cross-Industry Comparison of Productivity Growth.” Journal of Political Economy 101:207-22.

Christiansen, L. R. D. Cummings, and D. Jorgenson. 1980. "Economic Growth, 19471973: An International Comparison.” In J. W. Kendrick and B. Vaccara (eds.), New Developments in Productivity Measurement and Analysis. Studies in Income and Wealth, Vol. 41, Chicago: University of Chicago Press.

De Long, J. Bradford. 1988. "Productivity Growth, Convergence, and Welfare. Comment." American Economic Review 78(5):1138-54.

Denison, Edward F. 1962. Sources of Economic Growth in the United States and the Alternatives Before Us. New York. Committee for Economic Development.

- 1967. Why Growth Rates Differ. Washington, D.C. Brookings Institution.

Dougherty, Christopher. 1991. A Comparison of Productivity and Economic Growth in the G-7 Countries. Ph.D. dissertation, Harvard University.

Easterly, William. 1999a. "The Ghost of Financing Gap. Evaluating the Growth Model of the International Financial Institutions." Journal of Development Economics, December.

—. 1999b. "Life During Growth." Journal of Economic Growth 4(3):239-76.

—. 2001. "The Lost Decades. Developing Countries' Stagnation in Spite of Policy Reform 1980-98." Journal of Economic Growth 6(2):135-57.

Easterly, William, and Sergio Rebelo. 1993. "Fiscal Policy and Economic Growth. An Empirical Investigation." Journal of Monetary Economics 32:417-58.

Easterly, William, Michael Kremer, Lant Pritchett, and Lawrence Summers. 1993. "Good Policy or Good Luck? Country Growth Performance and Temporary Shocks." Journal of Monetary Economics 32:459-83.

Elias, Victor J. 1990. Sources of Growth. A Study of Seven Latin American Economies. International Center for Economic Growth. 
Fischer, Stanley. 1993. "The Role of Macroeconomic Factors in Growth.” Journal of Monetary Economics 32:485-512.

Frarikel, J. A., and David Romer. 1999. "Does Trade Cause Growth?” American Economic Review 89:379-99.

Fujita, Masahisa, Paul Krugman, and Anthony Venables. 1999. The Spatial Economy: Cities, Regions, and International Trade. Cambridge, Mass.: MIT Press.

Grossman, G., and E. Helpman. 1991. "Quality Ladders in the Theory of Economic Growth." Review of Economic Studies 58:43-61.

Grubel, Herbert G., and Anthony Scott. 1977. The Brain Drain. Determinants, Measurement and Welfare Effects. Waterloo, Ontario: Wilfrid Laurier University Press.

Hadjmichael, Michael T., Michael Nowak, Robert Sharer, and Amor Tahari. 1996. Adjustment for Growth. The African Experience. Washington, D.C.: IMF.

Hall, Robert E., and Charles Jones. 1999. "Why Do Some Countries Produce So Much More Output per Worker than Others?” Quarterly Journal of Economics 114(1):83116.

Hansen, Gary D., and Edward Prescott. 1998. "Malthus to Solow." NBER Working Paper Series No. 6858.1-24.

Hanushek, Eric A., and Dennis D. Kimko. 2000. "Schooling, Labor-Force Quality, and the Growth of Nations." American Economic Review 90(5):1184-1208.

Harberger, Arnold C. 1998. "A Vision of the Growth Process." American Economic Review 88(1):1-32.

Holmes, T., and J. A. Schmitz Jr. 1995. "Resistance to New Technologies and Trade between Areas." Federal Reserve Bank of Minneapolis Quarterly Review 19:2-18.

International Labor Organization. 1995. World Employment. Geneva.

Jalan, Jyotsna, and Martin Ravallion. 1997. "Spatial Poverty Traps?” World Bank Policy Research Working Paper No. 1862.

Jones, Charles. 1995a. "R\&D-Based Models of Economic Growth.” Journal of Political Economy 103:759-84.

- 1995b. "Time Series Tests of Endogenous Growth Models." Quarterly Journal of Economics 105(2):495-526.

- 1997. "Comment on Peter Kienow and Andres Rodriguez-Clare, 'The Neoclassical Revival in Growth Economics. Has It Gone Too Far?"” NBER Macroeconomics Annual 12:73-103.

- 1999. "Was an Industrial Revolution Inevitable? Economic Growth Over the Very Long Run." Stanford University, mimeo.

Jorgenson, Dale W. 1995. Productivity. Cambridge, Mass.: MIT Press.

Kendrick, John W., and Elliot S. Grossman. 1980. Productivity in the United States: Trends and Cycles. Baltimore, Md.: Johns Hopkins University Press.

King, Robert G., and Ross Levine. 1994. "Capital Fundamentalism, Economic Development and Economic Growth." Carnegie-Rochester Conference Series on Public Policy 40:259-92.

King, Robert G., and Sergio Rebelo. 1993. "Transitional Dynamics and Economic Growth in the Neoclassical Model." American Economic Review 83:908-31.

Klenow, Peter. 1998. "Ideas versus Rival Human Capital. Industry Evidence on Growth Models." Journal of Monetary Economics 42:2-23. 
Klenow. Peter, and Andres Rodriguez-Clare. 1997a. "Economic Growth. A Review Essay." Journal of Monetary Economics 40:597-617.

- 1997b. "The Neoclassical Revival in Growth Economics. Has It Gone Too Far?" NBER Macroeconomics Annual 12:73-103.

Klitgaard, Robert, and Amand Fitschen. 1997. "Exploring Income Variations across Traditional Authorities in KwaZulu-Natal, South Africa." Development Southern Africa 14(3).

Kongsamut, Piyabha, Sergio Rebelo, and Danyang Xie. 1997. "Beyond Balanced Growth.” University of Rochester Working Paper.

Kosmin, Barry A., and Seymour P. Lachman. 1993. One Nation under God. Religion in Contemporary American Society. New York: Harmony Books.

Kremer, Michael. 1993. "O-ring Theory of Economic Development.” Quarterly Journal of Economics 108:551-75.

Krueger, Alan B., and Mikael Lindahl. 1999. "Education for Growth in Sweden and the World.” NBER Working Paper Series No. 7190.1-54.

Krugman, Paul R. 1991. Geography and Trade. Cambridge, Mass.: MIT Press.

-1995. Development, Geography, and Economic Theory. Cambridge, Mass.: MIT Press.

. 1998. "Space. The Final Frontier." Journal of Economic Perspectives 12:161-74.

Krugman, Paul R., and Anthony J. Venables. 1995. "Globalization and the Inequality of Nations." Quarterly Journal of Economics 110(4):857-80.

Lipset, Seymour Martin. 1997. American Exceptionalism. A Double Edged Sword. New York: Norton.

Levine, Ross, and David Renelt. 1992. "A Sensitivity Analysis of Cross-Country Growth Regressions.” American Economic Review 82(4):942-63.

Levine, Ross, Norman Loayza, and Thorsten Beck. 2000. "Financial Intermediation and Growth. Causality and Causes.” Journal of Monetary Economics 46:31-77.

Lewis, W. A. 1954. "Economic Development with Unlimited Supplies of Labor." Manchester School of Economic and Social Studies 22(2):139-91.

Lucas, Robert E., Jr. 1988. "On the Mechanics of Economic Development.” Journal of Monetary Economics 22:3-42.

1990. "Why Doesn't Capital Flow from Rich to Poor Countries?” American Economic Review, Papers and Proceedings 80:92-96.

-1998. "The Industrial Revolution. Past and Future." Mimeo, University of Chicago.

Maddison. Angus. 1995. Monitoring the World Economy, 1820-1992. Paris: Development Centre of the Organisation for Economic Co-operation and Development.

Mankiw, N. Gregory. 1995. "The Growth of Nations.” Brookings Papers on Economic Activity 1:275-326.

Mankiw, N. Gregory, David Romer, and David N. Weil. 1992. "Contribution to the Empirics of Economic Growth.” Quarterly Journal of Economics 107:407-37.

McGrattan, Ellen R. 1998. "A Defense of AK Growth Models.” Quarterly Review, Federal Reserve Bank of Minneapolis 22:13-27.

Mellinger, Andrew D., Jeffrey D. Sachs, and John L. Gallup. 1999. "Climate, Water Navigability, and Economic Development." Harvard Center for International Development Working Paper No. 24. 
Mokyr, Joel. 1992. The Lever of Riches. Technological Creativity and Economic Progress. New York: Oxford University Press.

Murphy, Kevin M., Andrei Shleifer, and Robert Vishny. 1989. "Industrialization and the Big Push." Journal of Political Economy 97:1003-26.

Nehru, Vikram, and A. Dhareshwar. 1993. "A New Database on Physical Capital Stocks. Sources, Methodology, and Results.” Revista de Análisis Económico 8(1):37-60.

Nordhaus, William. 1994. "Do Real Output and Real Wage Measures Capture Reality? The History of Lighting Suggests Not.” Yale Cowles Foundation Discussion Paper 1078.

Parente, Stephen. 1994. "Technology Adoption, Learning-by-Doing, and Economic Growth." Journal of Economic Theory 63:346-69.

Parente, S. L., and E. C. Prescott. 1996. "Barriers to Technology Adoption and Development." Journal of Political Economy 102(2):298-321.

Patrinos, Harry Anthony. 1997. "Differences in Education and Earnings across Ethnic Groups in Guatemala." Quarterly Review of Economics and Finance 37(4):807-21.

Prescott, Edward. 1998. "Needed. A Theory of Total Factor Productivity." International Economic Review 39(3):525-32.

Pritchett, Lant. 1997. "Divergence, Big Time." Journal of Economic Perspectives 11(3): 3-17.

. 1999. "The Tyranny of Concepts. CUDIE (Cumulated, Depreciated, Investment Effort) Is Not Capital.” World Bank, mimeo.

- 2000. "Patterns of Economic Growth. Hills, Plateaus, and Mountains." World Bank Economic Review 14(2):221-49.

—. 2001. "Where Has All the Education Gone?" World Bank Economic Review. Forthcoming.

Psacharopoulos, George. 1994. "Returns to Investment in Education. A Global Update." World Development 22:1325-1343.

Quah, Danny. 1993. "Galton's Fallacy and Tests of the Convergence Hypothesis.” Scandinavian Journal of Economics 95(4):427-43.

Rappaport, Jordan, and Jeffrey Sachs. 1999. "The United States as a Coastal Nation." Harvard Center for International Development, mimeo.

Rauch, James E. 1993. "Productivity Gains from Geographic Concentration of Human Capital. Evidence from the Cities.” Journal of Urban Economics 34:380-400.

Ravallion, Martin, and Jyotsna Jalan. 1996. "Growth Divergence Due to Spatial Externalities." Economics Letters 53:227-32.

Ravallion, Martin, and Quentin Wodon. 1998. "Poor Areas or Only Poor People?” World Bank, mimeo.

Ray, Debraj. 1998. Development Economics. Princeton, N.J.: Princeton University Press.

Rebelo, Sergio, and Nancy L. Stokey. 1995. "Growth Effects of Flat-Rate Taxes." Journal of Political Economy 103:519-50.

Rodrik, Dani. 1998. "Where Did all the Growth Go? External Shocks, Social Conflict and Growth Collapses.” NBER Working Paper Series No. 6350.

Romer, Paul. 1986. "Increasing Returns and Long-Run Growth.” Journal of Political Economy 94:1002-37.

_- 1990. "Endogenous Technological Change." Journal of Political Economy 98:S71-S102. 
. 1995. "Comment on N. Gregory Mankiw, 'The Growth of Nations"” Brookings Papers on Economic Activity 1:313-20.

Rostow, W. W. 1960. The Stages of Economic Growth. A Non-Communist Manifesto. Cambridge: Cambridge University Press.

Shleifer, Andrei, and Robert Vishny. 1993. "Corruption.” Quarterly Journal of Economics 108(3):599-667.

Solow, R. 1956. "A Contribution to the Theory of Economic Growth.” Quarterly Journal of Economics 70:65-94.

-1957. "Technical Change and the Aggregate Production Function." Review of Economics and Statistics 39:312-20.

Todaro, Michael P. 2000. Economic Development, 7th ed. Reading, Mass.: AddisonWesley.

Union Bank of Switzerland. 1994. Prices and Earnings around the Globe. Zurich: United Bank of Switzerland.

United Nations. 1996. World Economic and Social Survey.

United States Government. 1996. 1995 Statistical Abstract of US. Washington, D.C.

World Bank. 1993. The East Asian Miracle. Washington, D.C.: World Bank.

- 1995. Latin America after Mexico. Quickening the Pace. Washington, D.C.: World Bank.

- 1999. World Development Report. Oxford: Oxford University Press.

- 2000a. Can Africa Claim the 21st Century? Washington, D.C.: World Bank.

- 2000b. East Asia. Recovery and Beyond. Washington, D.C.: World Bank.

- 2000c. The Road to Stability and Prosperity in South Eastern Europe. Europe and Central Asia Region, Washington, D.C.: World Bank.

- 2000/2001. World Development Report. Attacking Poverty. Washington, D.C.: World Bank.

Young, Alwyn. 1995. “The Tyranny of Numbers: Confronting the Statistical Realities of the East Asian Growth Experience.” Quarterly Journal of Economics 110:641-80. 